Este texto divulga resultados do projeto de pesquisa Estilemas Artísticos no Ofício de Carnavalesco na Cultura Popular Urbana do Espetáculo no Rio de Janeiro, que conta com financiamento do $\mathrm{CNPq}$, na modalidade de bolsa de produtividade em pesquisa (20142017)

** Pesquisador do CNPq; professor do PPGSOL/UnB e do PPMLS/cfy1UESB; pesquisador do $\mathrm{CMD} / \mathrm{UnB}$; editor da revista Arquivos do CMD.

\title{
6 Multimodalidade da Memória e a Sociologia dos a Priori Sociais
}

Edson Farias ${ }^{* *}$

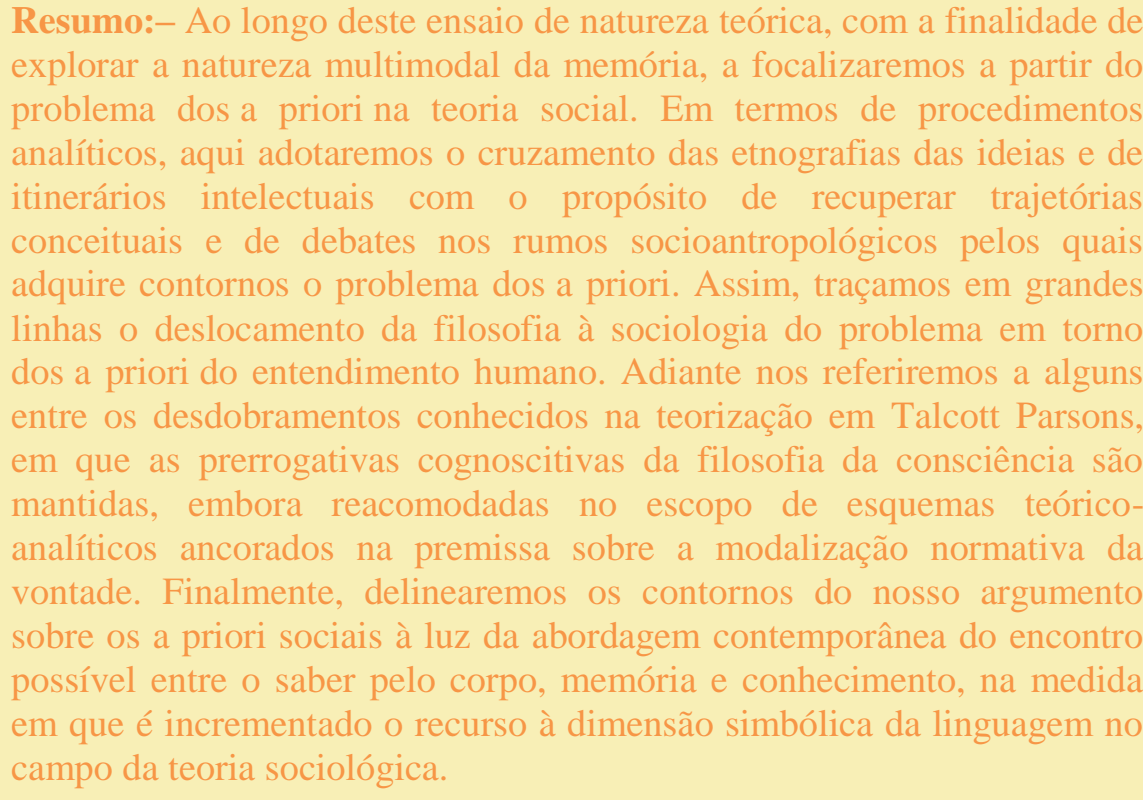

Palavras-chaves: Memória; Multimodalidade; A priori social; Teoria sociológica: Saber incorporado.

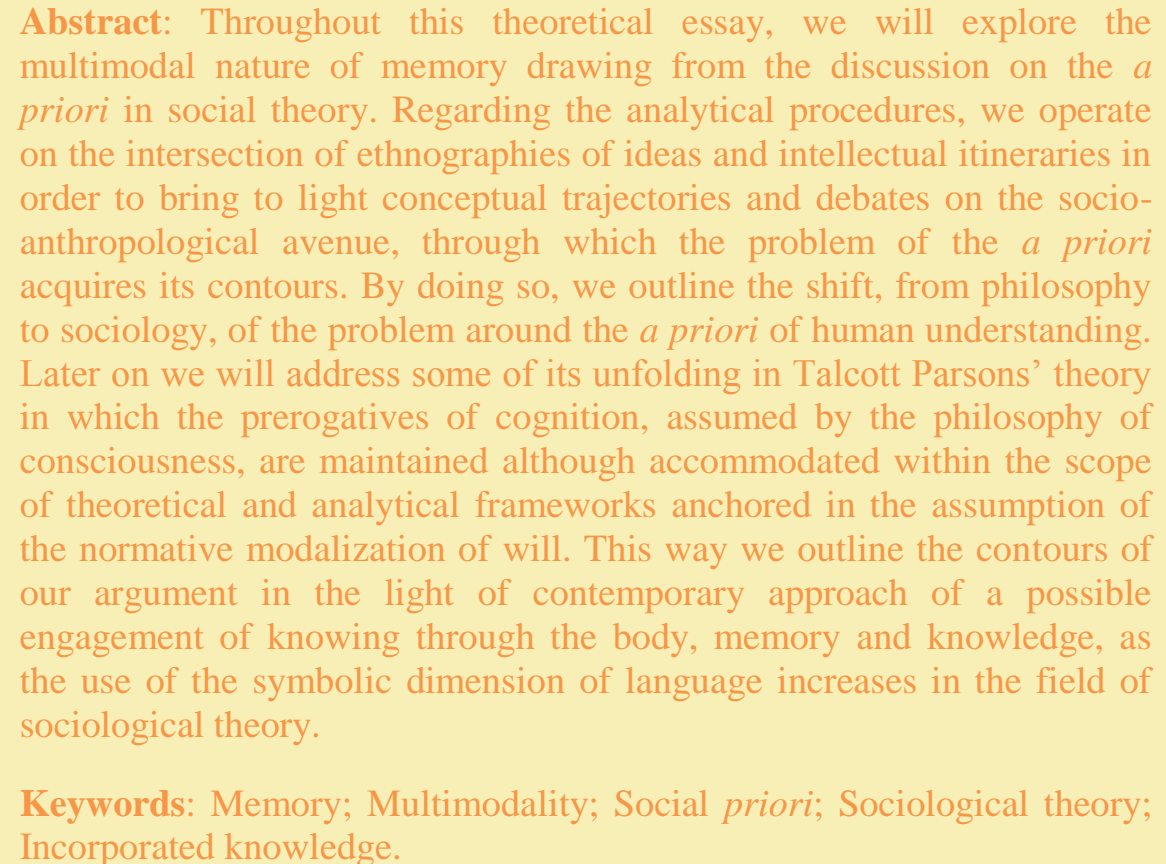

Abstract: Throughout this theoretical essay, we will explore the multimodal nature of memory drawing from the discussion on the $a$ priori in social theory, Regarding the analytical procedures, we operate on the intersection of ethnographies of ideas and intellectual itineraries in order to bring to light conceptual trajectories and debates on the socioanthropological avenue, through which the problem of the a priori acquires its contours. By doing so, we outline the shift, from philosophy to sociology, of the problem around the a priori of human understanding. Later on we will address some of its unfolding in Talcott Parsons' theory in which the prerogatives of cognition, assumed by the philosophy of consciousness, are maintained although accommodated within the scope of theoretical and analytical frameworks anchored in the assumption of the normative modalization of will. This way we outline the contours of our argument in the light of contemporary approach of a possible engagement of knowing through the body, memory and knowledge, as the use of the symbolic dimension of language increases in the field of sociological theory. 
A característica multidimensional do objeto de conhecimento memória traduz as maneiras mesmas como as tramas sócio-funcionais intrínsecas à montagem da esfera da ciência dispõem, em suas divisões, os limites postos aos e pelos mundos possíveis das respectivas disciplinas que dele se ocupam, mas segundo a prioridade conferida a apenas um entre os ângulos possíveis de abordagem. Neste sentido, como objeto intersticial entre diferentes focos disciplinares, a memória deixa entrever não apenas as fronteiras de cada uma dessas culturas cognoscitivistas, mas, principalmente, parece revelar o que supõem as divisões e seus efeitos sobre a produção do saber, pois exulta atentar aos modos de produção científica, ou seja, aos hábitos, costumes e enquadramentos institucionais; também às soluções ordinárias e às saídas contingenciais no tratamento dos temas e nas maneiras como naturaliza os diferentes pontos de vista como objeto a ser conhecido. Desse modo, sinaliza tanto as distintas culturas científicas, quanto os problemas que atravessam a formação e a dinâmica de determinados campos disciplinares.

Por exemplo. O debate a respeito da relação entre história e memória comporta o problema em torno do "fato histórico", por sua vez, este contém toda celeuma a respeito da identificação e da qualificação dos registros e fontes, que resultam na discussão acerca da confiabilidade das fontes orais. Incidência sintonizada com a emergência de outras maneiras de pensar a história - a exemplo da Escola de Anais e da New Left (BURKE, 2003) - e de fazer historiografia (DESAN LLOYD, 1998; VEYNE, 2008 HUNT, 1992, p.02-29; DESAN, 1992, p.63-96), como a etnohistória (FENTRESS \& WICKHAM, 1994, p.59-109). E, também, do status obtido por novos objetos de conhecimento, principalmente a "cultura popular", a qual tem sido resgatada nos rastros das pesquisas de autores, como Carlo Ginzburg (1987), Bollème (1988), Natalie Davis (DAVIS \& RANDOLF, 1989), Jacques Le Goff (1994), CERTEAU (1995), Jacques Le Goff e Pierre Nora (1995), Chartier (1995; 2002), Peter Burke (1991; 2010), entre outros. Convergentemente, as incorporações por parte de vertentes de historiadores do horizonte hermenêutico adotado pelo interpretativismo antropológico embutiram a sensibilidade relativa à importância das tramas dos significados e das elaborações nativas (BIERSACK, 1992, p.97-130).

Esses debates contracenam com a teorização sociológica a respeito dos quadros de lembrança, no sentido referido em $A$ Memória Coletiva, de Maurice Halbwachs (1990), e do procedimento etnográfico de pesquisa no relacionamento com alteridades não letradas e não urbanas. Quanto ao último aspecto, em especial, tornaram-se alvo de discussões as intervenções de folcloristas e etnólogos, ao se porem em pauta os modos de conceber a passagem do tempo e os trânsitos culturais, seja na construção dos objetos estudados, seja nos aportes de inferência analítica e interpretativa (KUPPER, 1988). Por sua vez, igual tema cruza-se com a discussão nas ciências sociais sobre a maneira como 
1 A esse respeito, sem dúvida, destaca-se a contribuição de Marcel Mauss (1974), no instante em que se interessou pela reinserção da dimensão psicológica no empreendimento

socioantropológico, mediante o projeto metodológico do "fato social total", em que o relevo e dado à interiorização por parte dos indivíduos das coordenadas da sociedade, tornando-se esta um vetor inconsciente (estruturalestruturante) das personalidades. Editado entre 1923 e 1924, na revista Année Sociologique, a partir da acepção da dádiva como ato de presentear que instaura a obrigação da reciprocidade, o autor propõe no texto Ensaios sobre o Dom: forma e raza da troca nas razão da troca nas Sociedades Arcaicas o esquema do "fato social total" dotado de caráter tridimensional. Esta tridimensionalidade, de acordo com Lévi-Strauss, faz coincidir a "dimensão propriamente sociológica com seus múltiplos aspectos sincrônicos; a dimensão histórica, ou diacrônica; e, finalmente, a dimensão fisiopsicológica" (LÉVI-STRAUSS, 1974, p.14). Uma das interpretações possíveis às inferências de Mauss é considerar a centralidade depositada por ele na troca, detendo o lugar de marco zero da interação humana. Assim, as interações são descortinadas à luz de um sistema a memória repercute no retorno às questões centrais que envolvem as categorias do entendimento e da socialização, da interiorização e da exteriorização. E isto leva, também, ao encontro com a psicologia do desenvolvimento, no que toca à relação entre tendência, condicionalidade, mimesis e aprendizado no debate sobre o comportamento, em especial, ao se aproximar do problema a respeito do inconsciente, pelo ângulo do entrecruzamento do imaginário e do pensamento (LEVY-STRAUSS, 2003, p.45-70; DURAND, 2001, p.375-434) ${ }^{1}$. Mas, também, quando insere o tema das representações sociais, no que toca à inscrição da subjetividade na intercessão entre sujeito, outro e objeto, trazendo para o primeiro plano da análise o consórcio entre mente (cognição), historicidade da consciência (julgamentos, atribuições e escolhas) e condições coletivas e históricas da experiência (MOSCOVICI, 2004; JODELET, 2008, p.25-46; ARRUDA, 2009, p.739-767).

Vemos, portanto, os vários rebatimentos de ordem metodológica, mas igualmente epistemológica das pesquisas e reflexões geradas a respeito da memória. $\mathrm{O}$ objetivo deste texto contracena, portanto, com o propósito de verificar como a questão da memória ajusta-se à propensão reflexiva a respeito do exercício mesmo do conhecer, isto ao considerarmos sua feição multimodal e interdisciplinar. Ou seja, é preciso levar em conta ser a compreensão da memória como objeto - como meio pelo qual se contornam impasses analíticos no estudo de outros objetos indissociável à intercessão de diversos saberes, definindo sua condição multimodal, por requerer o diálogo multidisciplinar. Nesse sentido, importa observar o quanto se faz evidente que, na contrapartida do quadro múltiplo de tematizações e convergências disciplinares, define-se igualmente uma demanda multidisciplinar de estudo da memória, que consiste na consideração da intercessão desses diversos saberes. Sua condição multimodal, com isso, diz respeito à característica de aliar, na condição de fenômeno psíquico-simbólico, aspectos bioquímicos com aqueles de ordem emocional, os quais estão referidos aos humores e trajetórias que modulam as pulsões dos indivíduos. Mas tais angulações de ordem biopsíquica não a encerram, já que se faz crucial apreender e interpretar a articulação entre a passagem do tempo e as alternativas de transmissão e expressão das experiências, o que define uma pauta na qual constam as regularidades institucionais e as molduras sócio-históricas presentes no delineamento daqueles domínios onde se processam a lembrança e o esquecimento.

Ao longo deste ensaio de natureza teórica, com a finalidade de explorar a natureza multimodal da memória, a focalizaremos à luz do problema dos a priori na teoria social ${ }^{2}$. Ao falar a respeito de a priori, persevera o argumento de que determinadas categorias do entendimento correspondem a estruturas cognitivas que modelam a percepção dos indivíduos e, na medida em que promovem, tanto a classificação, quanto a nomeação, têm efeitos sobre a direção das práticas. Mas, ao qualificá-las de social, a proposição fundamental é de tratar de meios de orientação da ação, 
abarcando os planos econômicos, jurídicos, familiar, técnico, religioso, entre outros. Ao mesmo tempo, deve estar o social encarnado tanto em uma biografia individual e, com isso, viabilizando observar a totalidade nos atos concretos e inteiros, quanto na individualidade de um "sistema de interpretação", coligando os tantos planos da vida social e biopsíquica.

Detendo-se na noção de mana, com ela se vislumbra a síntese, e esta, do ponto de vista do indivíduo participante da troca, evidencia determinadas equivalências entre o dar e o receber, isto é, " certo desvio de $\mathrm{s}$ mesmo e do equilíbrio institucional com os outros", em que a sociedade consiste no ato concreto da troca e nesta, a totalidade indivisível $\begin{array}{lr}\text { habilitadora das } & \text { permutas } \\ \text { (MERLEAU-PONTY, } & 1980,\end{array}$ p.195).

1980

2 O diálogo estabelecido com a ideia de "a priori histórico", tal como apresentada em Arqueologia do Saber, de Michel Foucault, refere-se à atenção conferida à proposta de história geral que relaciona "todo o domínio das instituições, dos processos econômicos, das relações sociais nas quais pode articular-se uma formação discursiva" (FOUCAULT, 2000, p.189) à questão dos "arquivos". Isto na medida em que este último diz por sintetizarem simbolicamente acervos coletivos de experiências e fornecerem certezas à apreensão e ao reconhecimento por parte de pessoas e grupos, favorecendo a tomada de posições destes últimos, a começar pela contextualização no espaço e no tempo. Logo, toma-se a ideia de a priori do ponto de vista sociológico, e isto equivale a reconhecer que tais molduras do entendimento humano são estruturas gnosiológicas, mas são relativas a processos sócio-históricos de estruturação de símbolos de comunicação e orientação dos atos. Isto é, aquelas categorias constituem práticas humanas elevadas à condição de modelos de outras práticas, pelo alinhamento histórico de certas agências humanas em arquiteturas institucionais consagradas na distribuição do conhecimento coletivo. Para tais a priori comporem as disposições corporais das pessoas, requerem processos de aprendizado possíveis em situações de interação mediante linguagens; situações concatenadas com determinações históricas que engendram objetividades institucionais, em meio a equilíbrios de poder entre facções sociais Desde que realizada a incorporação deste saber, uma realidade se torna familiar, natural, na maneira mesma como ocorrem atitudes que as estendem nas lembranças e nos esquecimentos.

Trata-se do esboço em torno da questão que envolve o entendimento humano e a compreensão social nos ajustes sóciohistóricos entre os equilíbrios de poderes intrínsecos a certos graus de interdependências sociofuncionais e as distribuições de recursos,

valorizados como propriedades simbólicas e discursivo-expressivas que competem, seja para delinear arranjos intersubjetivos, seja para atender ou não a composição de imagens de mundo e autoimagens envolvidas com afetividades ${ }^{3}$. Esta discussão supõe a convergência de caminhos no campo das ciências sociais e, ao mesmo tempo, assinala um protocolo multidisciplinar a ser desenvolvido ${ }^{4}$ Em termos de procedimentos analíticos, adotaremos o cruzamento das etnografias das ideias e de itinerários intelectuais (STOCKING, 2001, p.03-05) com o propósito de recuperar trajetórias conceituais e de debates nos rumos socioantropológicos pelos quais o problema em torno dos a priori adquire contornos no plano metateórico (referido a proposições ontológicas sobre o social) e no teóricoanalítico (relativo aos esquemas categoriais aplicados no tratamento de um contexto empírico de pesquisa) ${ }^{5}$.

$\mathrm{Na}$ exposição, obedeceremos ao seguinte itinerário: inicialmente, traçaremos um delineamento sumário da memória como fenômeno psíquico. Em seguida, atentaremos à maneira como a discussão sobre a memória respalda o problema acerca dos a priori do entendimento na teoria social, contudo insistindo na prerrogativa da natureza sociodiscursiva desses mecanismos psíquico-cognitivos. Para isto, partiremos do problema filosófico em torno do conhecimento para focalizar o deslocamento ocorrido no mesmo problema, mas no escopo da teoria sociológica com o advento da contribuição durkheimiana. Assim, traçaremos, em grandes linhas, o deslocamento, da filosofia para a sociologia, do problema em torno dos a priori do entendimento humano. Adiante 
respeito a tipos definidos de discursos apreendidos em suas específicas durações, compreendendo regras históricas e anônimas também específicas de formação pelas quais a multiplicidade dos enunciados contracena com a unidade discursiva.

3 Embora reconheçamos certa proximidade com a ideia dos enquadramentos sociais, tal como se apresenta na obra de Goffman (2012, p.33), em especial ao se referir a "esquemas fundamentais de compreensão", em razão da tônica analítica nas práticas a ideia de a priori social, aqui, não compartilha da ênfase depositada na intencionalidade.

${ }^{4}$ As formulações sobre os a priori sociais, neste texto, vem nos rastros de pesquisas que desenvolvemos tanto a respeito da universalização histórica das ideias de cultura e desenvolvimento quanto dos modos de orientação no contexto metropolitano brasiliense (ver FARIAS, 2013, p.51-83; 2015, p.05-20).

${ }^{5}$ Ainda que não seja nossa proposta fazer uma história conceitual, recorremos à proposição analítica de Koselleck, para quem é "apenas por meio da perspectiva diacrônica que se pode avaliar a duração e $o$ impacto de um conceito social ou nos referiremos a alguns entre os desdobramentos conhecidos na teorização em Talcott Parsons, em que as prerrogativas cognoscitivas da filosofia da consciência são mantidas, embora reacomodadas no escopo de esquemas teórico-analíticos ancorados na premissa sobre a modalização normativa da vontade. Para, finalmente, delinear os contornos do nosso argumento à luz da abordagem contemporânea do encontro possível entre o saber pelo corpo, memória e conhecimento, na medida em que é incrementado o recurso à dimensão simbólica da linguagem no campo da teoria sociológica.

\section{Um fenômeno psíquico}

Cânone do pensamento ocidental, a tradição filosófica grega delimita três dimensões primordiais do saber, logo da verdade: a ontologia (a pergunta sobre o ser; acerca da essencialidade do existente); a metafísica (a causa primeira e última; o princípio que informa a existência); e a epistemologia (a possibilidade de demonstração do como algo existe à maneira como se apresenta).

Evidentemente, escapam das possibilidades postas a este texto tanto atingir a mais primordial entre as propriedades da memória quanto dá conta do princípio básico que a fundamenta. Isto significa estar aqui situado no terreno da epistemologia, na medida em que voltaremos ao exercício de traçar um panorama como a memória está definida como objeto de conhecimento, como dissemos, disposto na encruzilhada de motivações próprias a diferentes campos disciplinares científicos - sem esquecer os trânsitos filosóficos que também a abordam ${ }^{6}$. No entanto, seria ingênuo imaginar o imediato descarte das dimensões ontológicas ou metafísicas, simplesmente ao reconhecer o enraizamento no propósito epistemológico. Afinal, um ponto de partida em qualquer discussão a respeito de algo é: qual é o objeto tratado? Neste caso, responderemos de pronto: a memória. Sem dúvida, mas em que consiste a memória? Como defini-la? Uns dirão: nos atos de recordação, nas lembranças espontâneas que nos invadem ou nos esforços de rememoração. Ao que outros podem acrescentar: os esquecimentos, dos quais somos tantas vezes vítimas.

O primeiro senão já desponta, porque lembrança e esquecimento se referem à memória, entretanto não lhe são sinônimos. Um e outro são atividades que envolvem imagens mediante as quais se produzem representações do passado, ou seja, a evocação presente de algo ausente, correspondendo, assim, às afecções deixadas em nós pelas impressões a respeito de algo e, também, do próprio acontecimento que as motivaram. Há, sim, aspectos físico-químicos relativos às operações neurocerebrais desenroladas no complexo nervoso central, deixando patente a composição material do fenômeno mnemônico. Se tais imagens que recriam situações, sentimentos e sensações já vivenciadas efetivam a memória, esta parece superá-las, sendo espécie de síntese por ultrapassá-las na natureza das suas respectivas 
político, assim como das suas respectivas estruturas" (KOSELLECK, 2006, p.105).

${ }^{6}$ Em outra oportunidade (FARIAS, 2012, p.11-54), procuro construir uma genealogia conceitual da ideia de memória como objeto de conhecimento. Para isto, lançamos um olhar retrospectivo aos que são tomados como estágios intelectuais e socioinstitucionais na discussão e estabelecimento desta tópica em contínuo vínculo com o problema composto em torno do triângulo tendência, entendimento e moralidade. Aleida Assman (2011, p. 31-67) oferece uma perspectiva desta trajetória a partir da distinção que estabelece entre dois paradigmas da memória: mnemotécnica (segundo Cícero) e recordação (vinculado ao conceito de "potência", em Nietzsche), sendo esta última tributária da maneira como Vico, deslocando-a da retórica, acomoda a memória na dimensão antropológica.

7 Kandel (2009) oferece um panorama bem ilustrativo do desenvolvimento das pesquisas no campo biomédico a respeito da memória, sobretudo, no que concerne à trajetória de investigações das células nervosas e suas repercussões no debate sobre a memória. $\mathrm{O}$ que mais chama atenção é que o autor se refere a funções de memória e como particularidades. Seria, então, a memória um órgão a mais do corpo ou, pelo menos, um setor de algum dos órgãos já conhecidos? Nada confirma tal suposição. Aliás, qualquer investigação foi incapaz, pelo menos até agora, de constatar o lugar da memória no escopo da biologia humana ${ }^{7}$.

Somos tentados a concluir ser a memória uma atividade do espírito, já que corresponde a um fenômeno de consciência, por implicar operações hermenêuticas, portanto, exegéticas e interpretativas, em que se coligem e correlacionam elementos já dotados de sentido (significados). É esta uma saída tentadora e merece ser explorada. A maior dificuldade em adotá-la, no entanto, é abraçar inopinadamente uma concepção metafísica - religiosa ou laica de subjetividade. Isto, no que toca à fonte motora dessa intervenção; ou seja, o mote volitivo partiria de onde? O cerne da dificuldade estaria no fato de que, para estudar a memória, seríamos levados a responder, por exemplo, sobre a existência de Deus e sua incidência na tessitura da alma (psique).

Uma vez mais, não devemos ter pressa em considerar ter posto de lado tal problema metafísico, já que ele nos perseguirá a todo o tempo. Afinal, estaremos adotando um princípio nas resoluções que tomarmos ao insistir ser a memória uma função do espírito, ainda que venhamos a concordar que a última palavra traduz o ser e fazer humanos, com seus predicados e acessórios imanentes à condição finita e histórica da espécie. Ao dizermos que a memória sintetiza lembranças e esquecimentos, concluímos sobre a competência da memória em reter ou excluir recordações. Estaria aí sua lei básica, a saber: selecionar, correlacionar e sintetizar imagens referidas a acontecimentos, sentimentos e sensações já ocorridas.

Deste modo, arriscaríamos uma definição parcial de memória, posta no seguinte enunciado: ao constituir processos de compreensão, a memória consiste em uma maneira de lidar, isto é, um modo de saber para tratar da sucessão dos eventos, dentro de uma programação que distingue entre a perspectiva (o futuro) e a circunstância (o presente), considerando o tema do antecedente (o passado). Desde já se estabelece uma relação simbiótica entre memória e a questão da temporalidade.

Diante desta precária definição, somos remetidos outra vez à maneira de qualificar e reconhecer o que estamos chamando de espírito. Certamente, não fazemos referência ao tempo denso e continuamente eterno do divino - nos termos da narrativa da providência, por exemplo. Nossa consideração tem por alvo o tempo mundano, mas restringido ao sujeito das lembranças e dos esquecimentos, cujo marco empírico está naqueles que experienciam acontecimentos, sentimentos e sensações e podem, depois, elaborar imagens de tais acontecimentos, até mesmo os tornando partes de exercícios de imaginação. Incontornavelmente, a memória está inserida no cosmos por intermédio da existência humana, relativa à combinação entre imanência da morte e consciência da passagem do tempo - entre o antes e o depois, 
existem diferentes tipos ("explicita" e "implícita") de memórias. No entanto, a todo tempo fala de regiões do cérebro onde essas memórias se processam, sem enunciar precisamente a existência da memória como parte da morfologia neurocerebral (KANDEL, 2009, p.135-170).

${ }^{8}$ Cabe anotar que se parte, aqui, de uma concepção fenomenológica de mundo, para qual a atitude compreensiva se realiza sempre, continuamente, mediante sentidos primordiais forjados na interseção da subjetividade e da intersubjetividade na medida em que consiste na unidade pela "retomada das minhas experiências passadas em minhas experiências presentes, da experiência do outro na minha." (MERLEAU-PONTY, 1999, p.18).

9 Para um panorama amplo a respeito dos debates sobre a memória nesse último subcampo do conhecimento, ver GARRIDO \& conhecimento, ver GARRIDO \&
GARCIA-MARQUES $\quad(2003$, p.323-339).

10 Vale observar que a ideia de prática, aqui, não se identifica à concepção de "arte" de rememorar tal como aparece em autores grecolatinos antigos e na obra de Frances Yates (1966).

${ }^{11}$ Ou seja, a memória compõe-se e, enfim, o tempo transcorrido (RICOUER, 2007, p.35). O espírito, portanto, é uma metáfora de humanidade, entendida como gênero e indivíduo constituindo uma unidade, o mundo afetivo-simbólico ${ }^{8}$.

Uma armadilha possível, agora, é substancializarmos a humanidade, fazermos do conceito um fato empírico indiscutível. Esqueceríamos ser a humanidade, na mesma medida de que se trata de uma ontologia histórica, constitui-se em um nome/valor e, como toda nomeação com seu teor valorativo, a sua condição histórica lhe condiciona aos correlatos de interdependências sociais para se manter como parâmetro das condutas. Contudo, como não nos resta tanta margem de manobra, iremos, aqui, nos servir deste parâmetro. Imediatamente já somos alertados para um primeiro efeito da "opção": nosso olhar para memória se concentrará no saber das humanidades e deixaremos em um plano secundário as elaborações das ciências ditas neurobiológicas, mesmo da psicologia cognitiva 9 . Porém, extrapola os objetivos deste texto qualquer esforço de síntese dos saberes das humanidades sobre a memória (ver SMOLKA, 2000). Ressaltamos o interesse em apenas angariar subsídios cognitivos nessas áreas para ajustar nossa definição. Assim, diríamos ser a memória uma função do espírito, uma prática, logo, uma atividade de conhecimento, cujo objeto é o tempo pretérito, atividade que se realiza sobre as representações do passado $^{10}$. Diz respeito, portanto, à atividade extrassensorial, não ao se fazer indiferente aos sentidos corpóreos, mas porque os ultrapassa em suas respectivas particularidades. Enfim, a nosso ver, a memória é uma atividade psíquica, já que envolve exercícios autocompreensivos - de apreensão e, também, doação de nexos de sentido possíveis mediante as experiências.

Por outro lado, a transcendência da memória, em relação às sensações corporais de indivíduos, assinala que, ao tratar dos sentidos como concatenações de sentimentos e valores, ela se inscreve no conjunto simbólico, ou seja, no universo humano dos esquemas de percepção e das malhas de significados que traduzem o contínuo em diferença, no encadeamento entre idêntico e diverso e, assim, possibilita a experiência com seus ambientes e objetos, ao qualificar atos, coisas, eventos e sensações. Inteirada ao simbólico, a memória compõe-se igualmente nas (e das) reciprocidades sóciohumanas ${ }^{11}$. Anotamos o quanto intrínseco se faz, portanto, à luz de tal panorama, o tripé composto por linguagem, memória e social, deixando entrever a natureza multifacetada desta última como fenômeno, conectando, nele, um leque de processos cognitivos e simbólicos inseridos nas interdependências sócio-funcionais, portanto, compondo e qualificando as dinâmicas históricas de permanência, mudança e ressignificação. Estas dinâmicas envolvem os domínios de retenção e controle da lembrança e do esquecimento: monumentos, documentos e outras representações dos saberes, rituais e celebrações, as performances e demais meios de expressão em que a memória concatena as práticas; miríade de aspectos e processos que exigem atenção para a pesquisa e a reflexão sobre os procedimentos, os princípios teórico-analíticos e 
igualmente, constitui o que Cassirer denomina de "rede simbólica", no sentido de um encadeamento de nomeações que intermedia as pessoas entre si e com os elementos do universo físico (CASSIRER, 2005, p.45-49). os suportes institucionais internos às diferentes competências disciplinares no tratamento desse mesmo leque por meio da visada multidisciplinar.

Característica prismática esta reveladora do quanto o tema da memória incide reflexivamente sobre o problema mesmo do conhecimento. Afinal, é possível, por seu intermédio, indagar acerca dos fundamentos de determinadas prerrogativas consagradas a respeito do conhecer. Mesmo correndo o risco empobrecedor contido na generalização, poderíamos sintetizar tais prerrogativas recorrendo às duas vertentes de maior repercussão no campo filosófico e científico do Ocidente: os regimes de verdades respectivos da ontologia e da metodologia. Enquanto uma, herdada da matriz socrático-platônica, advoga o conhecimento como atividade orientada pelo mestre, visando ao reconhecimento dos plenos e estáveis pilares conceituais da existência; a outra, tendo por marco a intervenção cartesiana, desqualifica o saber como estoque em nome do procedimento metódico e disciplinador da prática cognitiva em observância do critério de levar ao crivo da dúvida toda e qualquer proposição cujo objetivo seja adquirir o status de representação da verdade, ou seja, de certeza.

Ora, o debate acerca da memória comparece em ambas as vertentes. Se, na primeira, o conhecimento é entendido como intrínseco ao exercício mnemônico, na outra, a atividade cognoscente é exultada a se realizar justamente se desvencilhando dos quadros de lembrança, inclusive forçando o seu desmonte. No entanto, o tema da memória os atravessa, deixando rastros que interrogam a prerrogativa principal inerente a cada um desses regimes de verdade, pois, de um lado, cobra do primado da permanência quais respostas é capaz de dar aos efeitos da passagem do tempo sobre a continuidade. Ou seja, indaga-se a tradição no tocante aos mecanismos de aprendizado, educação e legitimação, aos quais pode recorrer para superar ou, pelo menos, atenuar as pressões oriundas da passagem do tempo com suas inevitáveis vicissitudes. Enfim, como é possível a tradição se manter inteligível e legível na medida em que garanta a autoridade de consistir no horizonte absoluto de compreensão, explicação e interpretação dos fatos, da vida e do mundo em geral?

Ao contrário, o tema da memória irrompe no plano da verdade metodológica, fazendo interceder, nela, a dimensão simbólico-discursiva constituinte de toda prática humana, mesmo daquelas cuja autoimagem opera a partir da premissa de possuir e tornar viável a transparência racional da totalidade do real histórico e empírico (TAYLOR, 2000). Isto porque já que estaria desenraizada de qualquer contexto e, logo, não pertenceria a qualquer dos cosmos. O que se torna alvo aí é a desatenção à presença dos saberes armazenados e sintetizados, quer nas palavras cotidianas, quer nos gestos ordinários, mediante os quais o agente do conhecimento se movimenta no dia a dia científico ou não, significando atos, coisas e cenários da sua ação e das de outros. Conclui-se que falar de memória nesse âmbito de verdade é 
sublinhar a permanência, a tradição, nos elementos tácitos quase invisíveis, mas que cumprem papel elementar na inteligibilidade e comunicação das atividades e produtos do conhecimento, mediante as tramas intersubjetivas que conformam as interações e as formações subjetivas.

Notamos, portanto, que a natureza multimodal da memória e sua incidência no debate epistemológico indicam a imperativa atenção a ser dada às mediações exercidas pela transformação das experiências em saberes e, desde aí, da transmissão simbólica desses modos de saber, agir e pensar interferindo na modelação dos impulsos vitais, facultando o autocontrole e o controle, na medida em que se fazem objeto e meio de aprendizados. E, com isso, repercutem na atualização e, sobretudo, obrigam a considerar o papel central do conhecimento na existência e manutenção da tensa, mas estrutural reciprocidade entre os modos de subjetivação das exterioridades e a objetivação das atitudes. Justamente por isso, exige-se o olhar atento às maneiras mesmas como incidem saber $\mathrm{e}$ fazer no deslocamento dos estoques de conhecimento e estando estes deslizamentos em sintonia com formações sociais, dispositivos institucionais de coordenação sistêmicos e comunicativos dos comportamentos e, logo, equilíbrios de poder com suas respectivas fórmulas de legitimação.

Sabemos, essa é uma discussão intrínseca às preocupações das ciências sociais, em particular àquela sobre incorporação de saberes, aprendizados, modos de orientação do agir e práticas. Com o emprego de descrições densas de ideias, a finalidade de traçar um quadro não exaustivo do percurso intelectual em que ocorre a triangulação entre esses três últimos aspectos, nas próximas seções nos ocuparemos da correlação entre memória e as linhas-gerais do tema dos a priori sociais, visando sublinhar os limites disciplinares e, ao mesmo tempo, as incitações ao diálogo transdisciplinar que requer essa saída vinculada diretamente à questão dos processos mnemônicos.

Uma rotação intelectualista: dos neokantianos franceses às representações coletivas em Durkheim

Com nítida filiação à proposta intelectualista do criticismo kantiano, no conjunto da obra de Durkheim chama atenção a importância do tema das representações coletivas. Às representações coletivas confluem, no esquema teórico-analítico proposto pelo autor, os esforços com vistas a proporcionar status de ciência autônoma à sociologia, além ainda do lugar-tenente ocupado pelo problema em torno das categorias do entendimento humano. Afinal, o projeto da Escola Francesa de Sociologia era saber o que pensam os homens e quais são aqueles designados pelo pensamento, mas do ponto de vista do problema em torno da atividade cognoscente da sociedade sobre si mesma e, assim, com prioridade posta no modo como são construídos os estados da consciência coletiva, os quais seriam básicos à vida grupal e ao sentido pensado e compartilhado entre os seus membros 
12 Como argumenta Geoffrey Hawthorn (1982, p.118-119), ao longo desse período a França conheceu a retomada permanente das mesmas questões, as quais deixaram em xeque a estabilidade institucional do país, na medida em que as batalhas entre monarquistas e republicanos ativavam rancores mútuos.

${ }^{13}$ Sobre esse aspecto, é possível destacar dois expoentes notáveis na polarização descrita e elementar à sociedade industrial no mundo europeu da primeira metade do século XIX, cujas propostas obtiveram repercussão na montagem da ciência social. De um lado, August Comte e o projeto de reorganizar a
(OLIVEIRA, 1979, p.33). Daí as representações coletivas apresentarem envergadura universal:

(...) Elas - as representações coletivas - correspondem às propriedades mais universais das coisas. Elas são como quadros rígidos que encerram o pensamento; este parece não poder libertar-se delas sem se destruir, pois não parece que possamos pensar objetos que não estejam no tempo e no espaço, que não sejam numeráveis etc. As outras noções são contingentes e móveis; nós concebemos que elas possam faltar a um homem, a sociedade, a uma época; aquelas nos parecem quase inseparáveis do funcionamento normal do espírito. São como a ossatura da inteligência (...) (DURKHEIM, 1989, p.513)

Diante da sumária explanação das bases epistemológicas, a discussão durkheimiana é heurística dos propósitos desta explanação no instante em que se mostram decisivos os seguintes deslocamentos no debate sobre ordem e entendimento: da filosofia para a ciência social, da razão pura para a razão social. Para apreender o quanto de agudo há nestes deslocamentos se faz urgente incluí-los naquele debate intelectual-acadêmico posto na matriz da própria Escola Sociológica Francesa. O aprofundamento realizado por Durkheim e seus colaboradores nas categorias do entendimento, inserindo-as no concerto histórico e sociocultural, ainda que vivido como "natureza" nas representações coletivas, fora sem dúvida radical para a conformação da sociologia como discurso sobre a verdade e disciplina científica autônoma, justamente ao tomar da filosofia a prerrogativa da investigação e interpretação do ordenamento e, no reverso, reconhecer na ideia mesma de ordem um valor, fonte primaz do bem, mais especificamente, o bem coletivo.

Algo assim se deu pela ruptura com o legado kantiano, contido na Crítica do Juízo Analítico, no contexto francês da segunda metade do século XIX, contexto fermentado pelo confronto entre correntes idealistas, de inspiração hegeliana, e ascendente onda neokantiana, alimentada em parte pelos resultados das sublevações liberais e restaurações aristocráticas estendidas desde a Revolução de 1789, grassando estalidos em 1815, 1847, 1851 e 1870 (KÖHNKE, 2011) ${ }^{12}$. Situação bipolar instaurada no campo intelectual, mas com repercussões políticas, seja nas iniciativas popular-revolucionárias, seja no bojo daqueles segmentos de características mais propensas a propostas reformistas. Em ambos, o ponto nevrálgico estava na interseção entre apreender as linhas mestras de tal arranjo social e, desde aí, intervir, fomentando, ou a ruptura, ou a reacomodação dentro dos princípios normativos estabelecidos. Inscrito nesse contexto, desponta o problema acerca das representações que orientam as condutas como objeto de interesse político e filosófico-científico ${ }^{13}$. Em se tratando da França, as vertentes kantiana e hegeliana, a um só tempo, enfrentaram-se e se fizeram complementares, no instante em que estavam em jogo os laços entre conhecimento e interesse.

Por intermédio da obra do filósofo de filiação neokantiana Octave Hamelim, Ensaio sobre os Elementos Principais da

Dossiê Multimodalidade da Memória: Narrativa e Teoria Social

Arquivos do CMD, Volume 4, N.1. Jan/Jun 2016 
As informações biográficointelectuais arroladas são extraídas de LUKES (1973).

15 Poderíamos a esse respeito especular sobre a proximidade entre Durkheim e Hegel, na medida em que para ambos o sujeito não consiste na consciência isolada, mas na antecedência do "nós". Ainda assim, certo cuidado deve
Representação, tais vertentes filosóficas repercutiram sobre a pretensão, mais tarde, da Escola Sociológica Francesa em desenvolver o estudo das categorias do entendimento das “sociedades e povos concretos, como condição prévia à compreensão do pensamento humano...” (OLIVEIRA, 1988, p. 28). A despeito de muitas celeumas, o círculo neokantiano francês retoma do criticismo do mestre aquele postulado de que a percepção humana é capaz de agir a partir de representações (referentes, a priori).

Obstinado com esta questão, se forma o célebre "trio brilhante" na Faculdade de Letras de Bordeaux: Hamelin, George Rodier e o jovem provinciano Émile Durkheim, de origem judaica, proveniente da cidade de Lorraine. Os três pensadores estiveram sob a inspiração dos estudos do igualmente neokantiano Charles Renouvier, na Escola Normal Superior, onde estudaram filosofia, na passagem das décadas de 1870 a $1880^{14}$. A ressonância do professor Renouvier nos jovens e futuros acadêmicos esteve aliada à atitude tenaz do mestre na defesa da dignidade do indivíduo, mas a articulando à moralidade e ao imperativo de uma prioridade da razão. Contudo, o apriorismo da razão para ele deveria estar subordinado aos ditames da prática. Tal postura era coerente com a ênfase republicana progressista compartilhada por intelectuais liberais ou socialistas na Terceira República Francesa. Não cabe esmiuçar agora as filiações e apropriações propiciadas por esse ambiente acadêmico e político com a finalidade de identificar até que ponto as proposições hegelianas ressoam em Durkheim (ver WEISZ, 1983, p.90-119). Vale ressaltar apenas que as transformações críticas levadas a cabo na reflexão de Kant por Durkheim se traduziram na afirmação das categorias do entendimento como históricas, e não tão somente lógicas, o que, óbvio, o afastou definitivamente de Hamelin. Ainda assim, à semelhança deste, Durkheim entende no espaço e no tempo categorias e adere à relação entre realidade e fenômeno. Ambos os predicados afirmam o postulado kantiano de que as categorias compõem um quadro sólido do raciocínio humano; não são contingentes como as demais representações, não podem faltar ao espírito como a ossatura ao corpo. Desse modo, Durkheim as reconhece - as categorias - como conceito e, desse modo, consagra a potencialidade delas à universalização, por serem capazes de transmissão a uma pluralidade de espíritos, a despeito e independente das respectivas extensões dos últimos, em razão das propriedades de aquelas, portanto, aplicarem-se a todos os entendimentos.

Algo assim permite ao autor eleger o conceito como representação coletiva por excelência, na medida em que é a plenitude da representação impessoal, geral e externa a qualquer dos estados da consciência individual. E, também, toma o conceito como a representação coletiva por excelência ${ }^{15}$, já que consistiria no ato do ser especial, a sociedade, de pensar as coisas da sua própria existência. Extraído de As Formas Elementares da Vida 
Religiosa, no trecho a seguir, ressalta-se a primordialidade da vida religiosa por estarem nela concentradas, na situação ritual do culto, as representações coletivas, o estado pleno da consciência social, sólida e impermeável:

Porque o que faz o homem é aquele conjunto de bens intelectuais que constitui a civilização, e a civilização é obra da sociedade. E assim se explica o pape preponderantemente do culto em todas as religiões, quaisquer que elas sejam. É que a sociedade só pode fazer sentir sua influência, se ela for ato, e ela só é ato se os indivíduos que a compõem estão unidos e agem em comum. É pela ação comum que ela toma consciência de si e se impõe; ela é, antes de tudo, uma compreensão ativa. Até as idéias e os sentimentos coletivos só são possíveis graças a movimentos exteriores que os simbolizam, conforme estabelecemos. Portanto, é a ação que domina a vida religiosa pelo simples fato de que ela tem por fonte sociedade. (DURKHEIM, 1989, p.290)

Por não terem como substrato o indivíduo, conclu Durkheim (1985, p.03), as representações coletivas advêm da exterioridade abrangente da totalidade social ou, ainda, dos grupos parciais nela encerrados. Ao se situarem fora dos indivíduos e terem independência em relação às consciências destes e, sobretudo, deterem a qualidade de superá-los, pela generalidade do coletivo, as representações coletivas se impõem; são coercitivas justamente porque correspondem a pressões sociais sobre os indivíduos (tendências internalizadas na consciência individual). As representações coletivas, ainda que sejam veiculadas nas ações de indivíduos, não lhes são inerentes, mas elas compreendem o complexo societário composto capaz de ultrapassar, assim, cada membro em específico e mesmo a soma das partes. Quer dizer, as crenças e práticas religiosas, as da moral, os inúmeros preceitos do direito, todas as manifestações da arquitetura coletiva impor-se-iam de fora ao indivíduo. As representações coletivas têm, enfim, caráter de "obrigatoriedade" - ao não dependerem do âmbito individual, mas derivarem de um "poder moral" a elas transcendente, à maneira de Deus (a própria transliteração da sociedade no sagrado contínuo, intocável, temível e adorado como o bem em abstrato e o supremo poder). Donde se conclui que, no entendimento de Durkheim, a integração de um sistema de ação é produzida no ajuste de um consenso assegurado normativamente, em razão do acordo com o papel desempenhado pelas representações coletivas, tendo em vista as etapas da diferenciação funcional-estrutural dos sistemas sociais. São as representações coletivas este elemento outro capaz de, ao exceder as consciências individuais, persuadi-las à integração, para além dos fins utilitários daquelas e estão, igualmente, na soldagem das ações humanas como partes de um sistema de valores últimos; são tais valores a justificativa primordial dos atos e, assim, mostram-se obrigatórios como o próprio bem perseguido. Outra vez o encadeamento entre moralidade e classificações sociais como mecanismo ordenador ajustando, correlacionando e dispondo pessoas e coisas aponta, assim, a primazia gozada pelo postulado da estabilidade no 
esquema teórico-analítico do autor, o qual contracena com os limites axiológicos da sua concepção de realidade.

Para Durkheim, na sua impessoalidade, as representações coletivas são formas cognitivas de adequação do sentir, além de crenças e de orientação das práticas que apresentam a propriedade marcante de existir fora das consciências individuais, irredutíveis às representações oriundas das impressões sensoriais. Mas não se pode, para ele, reduzir as categorias do entendimento a qualquer entre as representações coletivas, já que estas últimas podem variar de uma sociedade para outra. Segundo a concepção durkheimiana, como instrumentos primordiais do conhecimento e da comunicação humana, as categorias do entendimento constituem os referenciais à construção de outras representações coletivas, ou seja, todas as inferências que façamos da realidade, no ato de classificar e ordenar obediente a modelos fornecidos pela sociedade, têm por sustentáculo as categorias do entendimento por estarem justamente na condição de ajustar as discrepâncias do real, por meio dos dispositivos classificatórios e de ordenamento, os quais são apriorísticos e necessários, logo, universais (OLIVEIRA, 1993 p.03-04).

Escrito a quatro mãos com Marcel Mauss, no ensaio Algumas Formas Primitivas de Classificação, Durkheim traça exatamente a conexão existente entre racionalidades e modos de classificação e a "história do espírito humano", isto é, a razão universal. Os autores sublinham, porém, as totalidades- reciprocidades, ou seja, a sociedade como ente de precedência cognitivo-moral sobre os indivíduos como a fonte promotora do (e que fornece os subsídios ao) empenho lógico-taxonômico. Vale anotar que ambos já reconhecem uma via de mão dupla, pois a grade classificatória age mutuamente sobre as relações sociais que a geram:

O que caracteriza estas últimas (as classificações) é que as idéias são aí organizadas segundo um modelo fornecido pela sociedade. Mas, uma vez que a organização da mentalidade coletiva existe, é suscetível de reagir sobre a causa e contribuir para modificá-la. (DURKHEIM e MAUSS, 1981, p.419)

Eis aqui o ponto culminante da doutrina e do esquema teóricoanalítico durkheimiano, pois, no quadro delineado, as categorias de gênero ou as categorias de tempo (tendo por causa o ritmo da vida social) ou, ainda, a de espaço (pela ocupação do território pelo grupo), além das de força (representativa da ação compacta coletiva e base da categoria mesma de causalidade) e de totalidade (cuja abstração é a forma mesma da sociedade) sinalizam para o pesquisador que todo este construto intelectual se ergue sobre a premissa de que cabe - citando o autor - "submeter o variável sob o permanente, o individual sob o social” (DURKHEIM, 1989, p.518). Então, posto que o "pensamento lógico começa com o conceito, segue que ele - o pensamento lógico - sempre existiu. Não há período histórico durante o qual os homens viveram de uma 
${ }^{16}$ Sabe-se o quanto tal propriedade central da metodologia de Durkheim esteve no cerne das disputas intelectuais travadas por ele na demarcação do campo sociológico. Entre as discussões deflagradas a respeito, sem dúvida aquela envolvendo Gabriel Tarde representou um episódio ímpar. Afinal, ao contrário da tônica durkheimiana depositada na ordem e na generalidade em favor da reprodução, o último autor voltouse à "força da diferença". Na contramão do postulado homogeneizante das leis naturais, o seu ponto de partida é a granulação atômica e as fissões aí provocadas. Desse modo, as ordens seriam caracteristicamente finitas ao estarem subordinadas aos fenômenos da criação que apenas se daria mediante os transtornos. Ou nos seus termos, tratar-se-ia de "desordens criativas" em que múltiplas formas combatem umas às outras, aplicando-se em favor de se imporem como leis de uniformidade (TARDE, 2003, p.45-48).

17 Como observa Giddens acerca do posicionamento de Durkheim frente às concepções de imperativo moral e categorias a priori do entendimento em Kant: "Desde os estágios iniciais de sua carreira intelectual até (e inclusive) a publicação das maneira crônica na confusão e na contradição" (DURKHEIM, 1989, p.518)

Nesta crítica à ideia de pensamento pré-lógico, defendida por seu contemporâneo Lévi-Bruhl, evade o apelo ao primado da ordem, contido na característica de impessoalidade com a qual o autor descreve a imperiosidade coletiva dos quadros permanentes da vida mental. Precedência da razão social, ou melhor, dos apriorismos societários sobre as ideias individuais, vale recordar, os a priori sociais estão, agora, elevados ao status do critério de aceitação do que seja reconhecido como humano. $\mathrm{O}$ trecho seguinte é elucidativo em si mesmo: "Um homem que não pense por conceito não será um homem; pois não seria um ser social." (DURKHEIM, 1989, p.517). Vemos que o núcleo de todo o suposto está fundado em um mesmo ponto de partida dicotômico, alargado em espiral, qual seja: todo versus parte; coletivo versus individual; sagrado versus profano; complexo versus elementar; conceitos versus sensações; regras morais versus apetites sensuais E todos estão atravessados pela decisão a partir da qual Durkheim coloca a sociedade como substância suprema moral e motor das representações coletivas, o que, por sua vez, tem por alicerce a crença no fato de que a generalidade é o critério independente e orientador do individual $^{16}$ :

(...) a sociedade absolutamente não é o ser ilógico ou alógico, incoerente ou extravagante que muitas vezes comprazemos em ver nela. Ao contrário, a consciência coletiva é a forma mais elevada da vida psíquica, já que é uma consciência de consciências. Situada fora e acima das contingências individuais e locais, vê as coisas apenas pelo seu aspecto permanente e essencial que fixa em noções comunicáveis. Vendo do alto, ela vê longe; a cada momento do tempo, ela engloba toda a realidade conhecida; por isso somente ela pode fornecer ao espírito parâmetros que se apliquem à totalidade dos seres e que permitam pensá-los. Ela não cria esses parâmetros artificialmente, encontra-os em si, apenas toma ciência deles. Eles traduzem maneiras de ser que se encontram em todos os graus do real, mas que só no seu ponto mais elevado aparecem com toda clareza, porque a extrema complexidade da vida psíquica que aí se desenrola implica necessariamente maior desenvolvimento da consciência. (DURKHEIM, 1989, p.523)

Acatando, uma vez mais, a orientação de Pierre Bourdieu (2000, p.39-40) de que, nas ciências sociais, a ruptura lógica está, muitas vezes, implicada em rupturas sociais, notamos que os efeitos da elaboração de Durkheim a respeito do tema do entendimento humano são de amplas proporções. Diria estar no gesto durkheimiano muito do ponto de mutação ônticocosmológico, àquela altura do século XIX europeu, em que a antropoceia declina, ou melhor, é abarcada pela importância adquirida pelo gênero e espécie humana em suas impessoalidades: as historicidades e estruturas de ambas subordinam, nas teias das reciprocidades ou das interdependências biopsíquicas e sociofuncionais, o primado da razão subjetiva na condução do entendimento humano ${ }^{17}$. Não é casual o fato de Comte (1987, p. 41-94; BENOIT, 1999, p. 273-358) ter feito derivar a sociologia da biologia, principalmente na relação por ele estabelecida entre as sínteses orgânicas e os fenômenos de "psiquismo superior". Para 
Formas elementares $[$ da vida religiosa], Durkheim estava preocupado em reformular alguns dos principais conceitos da filosofia de Kant num contexto social. Ele tentou mostrar que tanto o imperativo moral quanto as próprias categorias da mente não devem ser considerados como algo a priori, mas ao contrário podem devem ser explicadas sociologicamente." (GIDDENS 1979, p.49-50)

ele, a ciência da sociedade, por entrecruzar o orgânico ao inorgânico, mas inserindo o elemento vital, antecipa o fenômeno do psiquismo resultante da dimensão cósmica constituída pela humanidade, na dupla face de espécie composta por indivíduos e o ente coletivo-histórico-moral. Nesse sentido, a antropoceia cede lugar à sociodiceia, isto é, o enlace de forças impessoais supraindividuais, mas mundanas, dispostas na explicação e justificativa dos infortúnios da vida, cumprindo agora à sociologia a tarefa de desvelar, nas redes das dependências mútuas entre pessoas e suportes institucionais, acomodados na história social e natural, as razões que determinam os destinos pessoais e do devir geral.

Habermas, mais recentemente, destacou a importância da proposição de Durkheim em vista da crescente complexidade gerada com a diferenciação funcional, a qual se inscreve na divisão do trabalho dos sistemas sociais modernos, mas diante da necessidade de integração simbólica vinculada às "regras morais ou normas que determinam a ação consensual dos participantes na interação" e não se confundem com as regras técnicas internas às interpelações instrumentais (HABERMAS, 1999, Vol. II, p.71). Ao contrário de Spencer, sublinha o pensador alemão, Durkheim descarta a possibilidade de uma regulação integradora, baseada no interesse privado agenciado pelo e no mercado capitalista. No esquema durkheimiano, importa identificar as regras morais que presidem a cooperação nas condições orgânico-funcionais das sociedades industriais, já que, entende ele, a carência de regulamentação social impede a cooperação entre as funções separadas, isto é, inviabiliza a solidariedade em um quadro de carências de normas. Logo, se a anomia é a carência de fins individuais e, na contrapartida, a sociedade traduz o conjunto de obrigações morais que liga os indivíduos, a moral só começa onde tem início a adesão a um grupo, seja ele qual for, o que torna o fato moral o impulso à mercê do qual "no constrangimento sobre nós mesmos, podemos agir moralmente, faz com que saiamos fora de nós próprios, eleva-nos acima de nossa natureza, o que não consegue sem dificuldade, sem contensão. E esse apetecível sui generis a que vulgarmente chamamos de 'bem'." (DURKHEIM, s.d., p. 210). A integração de um sistema de ação é produzida, enfim, no ajuste de um consenso assegurado normativamente, e isto se dá exatamente de acordo com o papel desempenhado pelas representações coletivas, tendo em consideração as etapas da diferenciação funcional peculiar às estruturas dos sistemas sociais. São as representações coletivas este elemento outro capaz de, ao exceder as consciências pessoais, persuadi-las à integração, para além dos fins utilitários, e faz das ações humanas parte de um sistema de valores últimos - justificativa primordial dos atos e tão obrigatória quanto o bem perseguido. Com isso, apesar de não estar ausente da sua arquitetura teórico-analítica, a contradição é resolvida em direta subordinação à concepção a respeito da 
18 Característica a respeito é a maneira como o autor insere o crime na discussão da normalidade e do patológico. Para constatar a eficiência do seu esquema, ele toma o crime como um fato mórbido a ser elucidado sociologicamente. A escolha recai na generalidade como o fenômeno é perceptível no conjunto das sociedades humanas, contudo se trata de um exemplo de normalidade quanto a sua inevitabilidade histórico-empírica, o que não se confunde com a valoração de bom ou de ruim. A partir dos seus caracteres externos, o crime é compreendido pela sociologia apenas como o ato que melindra os sentimentos coletivos A ofensa ocorre porque os sentimentos coletivos não estão simetricamente distribuídos nas consciências individuais. A existência de tal fato, porém, cumpre uma função latente, logo distinta do que verdadeiramente manifesta: a penalidade imposta ao infrator reforça o senso gera que foi maculado. Ao mesmo tempo, a utilidade social do crime para Durkheim está no papel que desempenha na evolução das espécies sociais. Considerando as influências sociais poderem impedir a apreensão igualitária da consciência coletiva pelo conjunto dos indivíduos, a discrepância se torna a oportunidade tanto para as ações individuais poderem ganhar integração moral e da totalidade sistêmica apresentada por Durkheim $^{18}$

Se, em Durkheim, o sujeito do entendimento é a sociedade, em lugar do eu epistêmico de Kant, tampouco a sociedade corresponde à consciência em sua epopeia até a emancipação, de acordo com a narrativa do "Espírito", em Hegel. Ainda assim, o autor não abre mão do imperativo da universalidade calcada na unidade de ordenação societal transpassando quaisquer experiências humanas e posta na impessoalidade do conceito, condição básica de todo o entendimento. Entretanto, constrange o mesmo princípio universalista ao lançá-lo no torvelinho da história, no instante em que advoga o indissociável vínculo das modalidades do entendimento com as diferentes formas e formatos das solidariedades sociais na transformação das sociedades simples para as complexas. Em se tratando do tema dos a priori, mantida a tônica na ordem social, desponta o dilema sobre as propriedades mediadas em sua unidade e quais são os modos operacionais desta unificação, tendo por materiais elementos díspares e heteróclitos entre si, mas também os fatores com incidência na sua reprodução, no tocante ao problema do tempo na tensão posta pela conjunção do controle com a conjuntura. Questões cujos desdobramentos ajudam compreender a maneira como o problema é reposto na teoria sociológica, no caudal da intervenção de dois grandes outros baluartes - Marx e Weber. À sua maneira, respectivamente, um e outro concluíram sobre: a) a ingerência da questão do conflito no enlace razão e história; e b) a alternativa de inserir a discussão sobre a legitimidade dos eixos de poder e dominação, na contrapartida funcional de apreensão dos consensos que alicerçam sistemáticas societárias, como parte do entendimento das próprias relações sociais ${ }^{19}$.

Já vimos como as representações coletivas elucidam metodologicamente a plataforma ontológica da qual parte Durkheim, afinal constituem os estados da consciência do sujeito coletivo - a sociedade - e são os fatos sociais por excelência, compreendendo o plano heurístico à observação empírica dos sociólogos. Notamos também haver um deslocamento epistemológico com sensível rebatimento sobre a dimensão filosófica, pois, ao situar na sociedade a fonte do conhecimento, o autor vira as costas a todo aquele centramento no homem, realizado pela tradição filosófica pós-cartesiana. Ao mesmo tempo, sua postura positivista procura o controle da razão mediante a experiência sensível, mas sem tripudiá-la como mero traço material da vida do indivíduo. A religião e a moral são, deste modo, reconhecidas como expressões desse equilíbrio. O entendimento de ambas revelaria o percurso que teria conduzido ao estágio positivo do conhecimento e, mais importante, uma e outra permitem descortinar as representações coletivas dotadas de independência em relação às consciências individuais. Antes, insiste Durkheim, as representações coletivas detêm a qualidade 
destaque quanto, também, algumas violações serem consideradas crimes, enquanto outras não. Isto porque é a sociedade o agente atribuidor do valor. $\mathrm{O}$ crime desempenha papel fundamental à evolução da moralidade e do direito. Algo assim ocorre porque a punição é uma reação da organização social à sua permanência, ou seja, à sua coesão. O crime evidencia, justamente, a não plenitude desta coesão da consciência moral, aponta-lhe à mobilidade, para a incompletude (DURKHEIM, 1985, p.61).

19 Valho-me da maneira como Immanuel Wallerstein (2002, p. 270) discrimina e descreve três axiomas, a seu ver, canônicos à cultura disciplinar sociológica. Esta teria por fundamento três "simples" proposições devotadas ao entendimento da realidade sócio-histórica. São elas: a "realidade dos fatos sociais", a "perenidade do conflito social" e a "existência de um mecanismo de legitimação para conter o conflito". A partir de igual ponto de partida, constituído em torno do problema da ordem nos fenômenos sociais, seguem os seguintes enunciados com a pretensão de serem evidentes em si mesmos. De início, a formulação de superar as ideias dos indivíduos e a elas se impor; são coercitivas, já que se trata das pressões coletivas sobre o comportamento de cada um dos membros isolados e, com o tempo, devido ao papel socializador da educação, tornam-se hábitos, isto é, tendências internalizadas na consciência individual.

Conforme Talcott Parsons, a concepção durkheimiana consiste em uma contribuição fundamental ao pensamento social porque, do ponto de vista lógico, fornece bases à investigação e explicação dos fenômenos da unidade na diversidade. Ao mesmo tempo, introduz referenciais ao entendimento do problema da integração/coesão e da ordem no interior de uma armação social bastante diferenciada. Nisto, propõe o sociólogo estadunidense, a categoria de representação coletiva desvela o quanto a estrutura de uma sociedade "ou de qualquer sistema societal humano, consiste em (não é meramente influenciado por) configurações da cultura normativa, institucionalizadas no sistema social e internalizadas (embora não de maneira idêntica) nas personalidades dos membros individuais." (PARSONS, 1977, p.88).

\section{A transição sintética parsoniana}

O projeto intelectual de Parsons se encerra na reunião de esforços para, ao sintetizar contribuições distintas no campo da teoria social, dotá-la de uma teoria geral da ação. Nesse sentido a escrita de The Structure of Social Action ocupa posição central nesse projeto como o momento inaugural do propósito de obter um funcionalismo sistêmico. Por outras palavras, a proposição teórica do livro se funda sobre a tese de que os sistemas sociais são, em última instância, sistemas de ações e que o tratamento analítico da estrutura desses sistemas opera desde o princípio sobre a existência empírica generalizada de pautas institucionalizadas, e não diretamente em termos de ação. Algo assim conduz ao estudo de dinâmicas processuais de ações consideradas à realização de papéis institucionalizados inscritos em equilíbrios, os quais, por sua vez, estão sob o duplo registro: ou da conformidade, ou do desvio frente às expectativas de papéis sancionados socialmente, mas igualmente de expectativa de papéis em conflito no tocante ao "indivíduo e as constelações de forças e mecanismos motivacionais implicados em tais balanças e conflitos.” (PARSONS, 1968, p.25).

Atendo-nos tão somente ao construto lógico-conceitual do projeto, observamos que lhe interessa a pavimentação do caminho epistemológico da sociologia, o que perfaz o tema mais geral da obra. Vale ressaltar, porém, que o intento esteve circunscrito à iniciativa de dar contribuição à sistematização teóricometodológica das ciências sociais sem privilegiar uma abordagem histórica. Daí por que o enfoque principal do livro é o tratamento estrutural-funcionalista ao problema da motivação, angulando-o do vínculo com as pautas culturais. Isto quer dizer que o marco do interesse está na atenção analítica aos problemas dinâmicos... 
(..) no contexto de sua relação tanto com a estrutura de um sistema como com a relação entre os processos e pré-requisitos de sua manutenção (que) fornecem um marco de referência para julgar o significado geral de um arranjo e para perseguir sistematicamente suas interconexões com outros problemas e fatos. (Idem, ibidem).

Tal evolução, para o autor, se centra nas relações entre os planos psicológicos e culturais da teorização sociológica, mas desdobradas em duas vertentes, as quais delimitam os objetivos inerentes à proposta da obra. A primeira, de natureza doutrinário-conceitual, corresponde à elaboração e aprimoramento teórico da análise estrutural-funcional dos sistemas sociais entendidos à luz da estrutura da ação social. Já a segunda é propriamente metodológica, no instante em que se volta para a operacionalidade de técnicas de investigação informadas pelo vocabulário conceitual resultante da elaboração anterior, o que, enfim, traduz a intenção de uma revisão capaz de promover uma síntese, cuja finalidade é revelar uma transição e transposição de um nível a outro de sistematização teórico-conceitual, ao recorrer aos esquemas legados por nomes decisivos da teoria social. Dessa maneira, esta última diz respeito ao corpo de uma mesma unidade, a despeito da tantas "escolas" que, no seu interior, concorrem no intervalo de um período histórico. Interessa-lhe justamente as contribuições à montagem do corpo doutrinal, perseverando esclarecer a estrutura e a utilidade empírica do sistema teórico fundado sobre um grupo de conceitos interconectados em relação a problemas empíricos que os transcendem e integram.
O recurso às obras de Marshall, Durkheim, Pareto e Weber, portanto, obedece a um critério de agrupamento calcado nos problemas empíricos internos às respectivas interpretações do capitalismo, como moderno sistema econômico, caracterizado por "regime de empresa" e "individualismo econômico" (ROCHER, 1976). Se o entendimento elementar ao livro é tomar a teoria social como único corpo de raciocínio sistemático, cujo desenvolvimento pode ser rastreado mediante uma análise crítica dos escritos que o possibilitam, incluindo aqueles seus predecessores, Parsons prioriza o estudo sobre o trinômio composto pelos vieses utilitarista, do idealismo e do positivista, relacionando-os à questão capitalista. É isto que o leva a notar a centralidade gozada pela ação humana no raciocínio utilitarista, enquanto enxerga no positivismo um esforço para equiparar as ciências sociais às naturais, evocando a objetividade das últimas, e destaca, finalmente, o quanto a dimensão espiritual da humanidade é ressaltada pela corrente idealista.

A hipótese do livro vem a reboque da suspeita deixada por Herbert Spencer ao perseguir as motivações histórico-estruturais para, na Europa Ocidental, terem se conjugados os elementos que levaram à transição culminada no advento da sociedade industrial (TURNER \& MARYANSKI, 1979). Entende Parsons que a resposta que oferece Spencer está subordinada à centralidade valorativa do individualismo, aspirada pelo próprio autor inglês, a qual se manifesta no pressuposto de que a iniciativa individual na 
busca dos seus interesses possibilita a satisfação das necessidades coletivas. Nesse sentido, a concepção sobre a religião que abraça refutaria a atividade religiosa como face de um estágio primitivo dominado pela ignorância, e o erro, tendência que teria sido suplantada à medida que a razão científica se impôs. No entanto, conclui Parsons, os inconvenientes lógico-teóricos estavam na indagação acerca dos efeitos da ciência sobre a ação humana, principalmente no tocante ao primado individualista, afinal, ao ser mantida a prerrogativa evolucionista, então, como entender e explicar o caminho que leva da religião à ciência?

De acordo com o ponto de vista relativo ao modelo de evolucionismo linear, Parsons se refere à revolução cognoscitiva vinculada ao peso concedido à refutação empírica das interpretações. Cada vez mais se daria margem a teorizações voltadas para encaminhamentos cíclicos e, por outro lado, ele percebe como no caudal desta circularidade ocorreria a ascensão de propostas que substituem o primado individualista pela centralidade do coletivo. $\mathrm{O}$ socialismo seria exemplar a respeito. Ainda nesse bojo viria à tona uma série proposições que deixa em xeque a primazia da razão em favor de outros aspectos na orientação e coordenação das condutas humanas. Com isto, o autor se impõe a tarefa de compreender a origem e a motivação para semelhante corte que, a seu ver, estaria no desenvolvimento imanente do corpo mesmo da teoria social a base da mesma alteração qualitativa apontada pelo exercício interpretativo, o que, portanto, justificaria o esforço dele em apreender a teoria como um sistema integrado, no interior do qual as proposições gerais consistem em enunciados sobre um modo de relações entre fatos. Tais modos estão em mútuas relações lógicas, ou seja, de intercâmbios necessários na formulação de sínteses de conhecimento e, simultaneamente, delimitam o que se faz imperativo conhecer.

O propósito de acompanhar o processo geral do desenvolvimento imanente da ciência social é solidário ao tema do livro, no instante em que este diz respeito à emergência da "teoria voluntarista da ação" como um sistema teórico recentemente agregado ao pensamento social. A iniciativa do autor, ao longo da obra, reside em verificar como este sistema teórico é afirmado pelos defensores nas suas categorias positivas frente ao que chama de "categorias residuais", isto é, um envolto de obscuridade que cerca as certezas basilares do próprio sistema, mesmo o deixando em contradição com os pilares lógicos. Entorno obscuro inerente ao movimento no qual se pergunta sobre as condições próprias de formulações de um sistema teórico voltado ao enfrentamento de questões empíricas, como observa o autor. De acordo com as prerrogativas defendidas por Parsons, trata-se, na escuta do desenvolvimento imanente da ciência, de saber como observações empíricas, associadas a categorias positivas de um sistema teórico, se transformam qualitativamente no movimento crítico decorrente da renovação da própria verificação empírica. Isto traduz para ele a 
proposição de que o progresso do conhecimento condiz com a alteração qualitativa da estrutura dos sistemas teóricos, e não com o mero acúmulo de dados.

Ao situar o objeto do estudo de The Structure of Social Action nesse marco, o autor burila a motivação que o levou à proposta do livro: empenho movido pelo objetivo de compreender o enlace entre certeza e ambiguidade, envolvendo a costura, alinhavando, no mesmo corpo doutrinário, ação humana e racionalidade pelo viés da teoria da ação voluntarista. A eleição do percurso atende, por sua vez, ao primado de entender a metodologia como consideração dos fundamentos gerais de validez das proposições de um estudo ante as observações realizadas. No caso em questão, no estudo do sistema teórico da ação voluntarista, estará em pauta o encadeamento observando a unidade priorizada na análise em suas conexões com outras partes. Assim o enunciado lógico da proposta do livro é descrito conforme o objetivo de apreender o traço estrutural do sistema da ação social (PARSONS, 1968, p.77).

No encadeamento dos capítulos, Parsons se debate com a herança do utilitarismo. A seu ver, caberia propor outro marco interpretativo ao caudal da formulação da teoria da ação que ultrapasse o parâmetro da ação racional pelo qual o indivíduo orienta sua conduta pela norma da eficiência, no tocante à adaptação às condições externas. E isto, ele acredita, deixa a teoria social à mercê do perigo atomista quando se trata de obter entendimento seguro da questão da ordem, na medida em que ressalta um individualismo que deixa a ideia de ordenamento em situação aleatória de instabilidade, por se subordinar aos atos de cada indivíduo, visando garantir a realização dos interesses próprios. $\mathrm{O}$ autor assinala a inconsistência do argumento liberalutilitarista, por ser incapaz de explicar como, aos esforços de um agente (a agência) em afirmar suas metas, escapa qualquer controle sobre as demais metas vinculadas às vontades alheias à sua. Com isto, ele propõe que a obtenção de êxito ou não por parte dos agentes requer um olhar atento à situação, a qual escapa em grande medida ao controle do agente e pode favorecer ou obstacularizar o acesso aos recursos, meios para que a ação torne viável a exteriorização das suas intenções. De acordo com Parsons, seriam efetivamente importantes aquelas restrições que permanecem inalteradas - as normas, que compreenderiam pautas compostas por expectativas ideais presentes às interpretações das diversas subjetividades, mediante as quais os indivíduos podem julgar a situação. Se as ações dos indivíduos adquirirem ajuste relacional com a situação graças à intervenção das mesmas normas, são elas os fatores por trás do êxito deles em atingir ou não as suas finalidades.

Na medida em que alia integridade individual e razão como um controle social mais amplo, Parsons propõe uma alternativa analítica multidimensional fundada na concepção de um voluntarismo indissociável da restrição normativa. Para isto ele 
redefine a compreensão da unidade-ato, anotando a existência, nela, de planos subjetivos e objetivos, tentando equilibrar as ordens instrumental e normativa. Os esforços e os meios, fatores objetivos, estariam, portanto, na contrapartida dos eixos reguladores. A ação estaria assim tensionada por um e outro plano, e ambos também se entrecruzariam nas grandes tradições que pavimentaram o caminho da teoria social. Para ele, se a ênfase recai nas normas, as tradições idealistas tendem ao coletivismo; já se priorizam o esforço, vão para o individualismo. No caso do viés materialista, ao privilegiarmos as condições, teríamos coletivismo; se abraçamos os meios, a opção é individualista. Como observa Giddens, a ideia de voluntarismo em Parsons é, desde o início, concebida como vinculada à resolução do problema da ordem, e esta é apresentada como a "coordenação das vontades individuais potencialmente desintegradoras". Cada vez mais, Parsons se empenhará em demonstrar que a resolução da questão da ordem no trato com o voluntarismo estará no estudo do modo como os atores internalizam, como motivos, valores compartilhados, os quais são básicos à coesão social. Desse modo, no seu esquema o empreendimento de explicar a ação tenderá à equação dos seguintes termos: de que maneira é demonstrável a sintonia entre uma teoria psicológica da motivação e uma interpretação sociológica das propriedades estruturais de sistemas sociais. O enunciado leva o seu esquema, em Social System (PARSONS, 1966), para o interesse em relação aos consensos de valor ou, mais especificamente, às ordens simbólicas. Com isto, de acordo com o seu vocabulário conceitual, a unidade-papel do sistema de interação se torna o ponto de cruzamento do "sistema social" e do "sistema de personalidade". Cabe à sociologia, a seu ver, atuar de maneira interdisciplinar com a finalidade de elucidar o problema em torno do ajuste entre sistemas diferentes, por serem constituídos de distintos complexos de existências adaptativas e integrativas. A questão em foco seria o tipo de coação que possibilita a interdependência entre ambos. A solução encontrada pelo autor convergirá na direção da ideia durkheimiana de que a "sociedade existe somente na mente dos indivíduos". Esta elucidação de fundo ideacional-cognoscitivo se realiza na opção pela premissa de que os padrões constitutivos da estrutura de um sistema, para obter a devida estabilidade, devem ser igualmente constitutivos do sistema de personalidade. Logo, com o emprego da ideia de culturacomum, o propósito está em demonstrar como tais padrões avançam para além das fronteiras dos sistemas de personalidades integradas a uma interação, isto é, os interpenetram.

Desde The Structure of Social Action, Parsons se viu às voltas com o problema da motivação do agente, em se tratando de compreender o seu vínculo lógico no corpo de uma teoria do sistema estruturado de ação (PAIXÃO, 1989, p. 34-56). A dificuldade estava em tornar recíprocos planos instrumentais e normativos da ação, ou seja, como fazer interdependentes a satisfação de interesses por parte dos indivíduos, na luta por 
${ }^{20}$ Em Social System, Parsons define quatro imperativos do paradigma funcional, mais popularmente conhecido como AGIL. Ou seja, o esquema encadeando "adaptação", "integração", "padrão de manutenção" e realização de finalidades como requisitos decisivos ao equilíbrio sistêmico. A função "A", de adaptação, refere-se ao problema do processo no qual o sistema se relaciona com ambiente externo no tocante à busca e distribuição de recursos necessários às suas atividades. Por sua vez, a função " $G$ ", realização de finalidades, consiste na formulação de bens pelos sistemas sociais e de motivações na mobilização desses já elaborados recursos. A função de integração concerne à questão interna dos processos de coordenação das varias relações organizando-as, assegurando a prevenção ou à solução das irrupções de conflitos. Finalmente, a função "L", padrão latente de manutenção e da tensão do comando, diz respeito a um modo igualmente de organização de problemas.

21 A novidade inserida pelo esquema parsoniano na teoria dos sistemas sociais está justamente na premissa de que residem nos dispositivos de inputs e outputs, pelos quais se estabelecem as relações de troca entre sistemas e ambiente, o procedimento que atender suas carências, e ainda, assim, se manter coerente com um ideário integrado às prerrogativas coletivas. A saída que tendeu o autor foi para a interseção entre sistema social de interação e sistema de personalidade, mediante a intervenção do que denominou "cultura comum". Vinculada aos quatro princípios funcionais ${ }^{20}$, para ele, centrais de um sistema, a cultura comum estaria na raiz da possibilidade de, justamente, cimentar um padrão compartilhado às condutas.

No entanto, dois problemas logo decorreram exigindo alternativas de elucidação. De um lado, como demonstrar os efeitos de generalização de valores dos dispositivos normativos, no respaldo das pautas de expectativas na orientação das condutas das unidades psíquico-biológicas? De outro, como lidar com o recurso estrutural-funcional diante do problema da mudança histórica e das alterações ambientais, além das nuances próprias aos organismos individuais inseridos nestas situações, sabendo da urgência de integrar as dimensões macro e microssociológicas? (TREVINO 2001). No prefácio à segunda edição de The Structure of Social Action, no mesmo compasso em que deixa patente serem as proposições de Boas, na antropologia social, secundárias aos propósitos de uma teoria geral da ação, frente ao legado deixado por Durkheim, Parsons sublinha estar uma das limitações do seu livro no descaso aos aspectos psicológicos do esquema conceitual da teoria social. Anota a contribuição, de todo um curso geracional, centralizado na figura de Freud, exatamente, à evolução do pensamento nessa mesma direção, e, apesar da diferença nos pontos de partida e nos interesses empíricos, ele sinaliza a imperiosidade de retomar a contribuição freudiana à revisão do livro, considerando-a tarefa indispensável à realização dos objetivos, pois os alargaria. Bem evidente que, nesse momento, Parsons tentava sanar aquelas dificuldades do seu raciocínio, que vinham à tona, e que se revelavam na exígua margem à compreensão e tratamento conceitual dos processos cognoscíveis próprios aos agentes sociais.

Cada vez mais, no avanço do seu percurso, Parsons se viu pressionado a conceituar a aliança capaz de proporcionar o ajuste sistêmico de partes em equilíbrio, o que determinou uma atenção maior, principalmente a partir da década de 1950, ao fluxo informacional intrasistêmico. $\mathrm{O}$ auxílio da cibernética e, nela, das teorias do código e da informação foi decisivo ao redimensionamento do seu esquema conceitual-analítico ${ }^{21}$. Desta maneira retomou o problema acerca das entradas (inputs) e saídas (outputs) de recursos, à luz da teoria sobre os controles informacionais das condições energéticas. Pôde, assim, reelaborar as cinco funções dos sistemas de ação como expressão de um modelo de hierarquia. Haveria, então, funções no controle do desenvolvimento do sistema de ação, funções de canalização, mediante fluxo informacional, e outras estariam ocupadas no fornecimento de energias demandadas pelo mesmo desenvolvimento. Resulta uma imagem piramidal hierárquica, em 
mantém os sistemas ordenados, em equilíbrio, diante do perigo da entropia que lhes ameaça a diferencialidade (BUCKLEY, 1974, p. 45-54). cujo pináculo estariam as funções culturais de fornecimento de padrões-valores básicos à estruturação da ação por meio da internalização de valores durante a socialização. A modelagem cibernética se apresenta como uma saída interpretativa para o autor se voltar mais de perto às articulações das ações com as condições físico-ambientais. Desde aí ele investe na investigação dos modos como se daria o controle dos atores no plano mesmo das suas atuações em papéis sociais, tentando considerar, para isto, como as dimensões físico-químicas do organismo são atravessadas pelos fluxos informacionais contendo os valores de orientação e visando extrair disso as conexões entre os eixos normativos societais e as tomadas de decisões dos atores na execução de finalidades que lhes demandam energias. Enfim, volta ao que deixou em descoberto no texto de The Structure of Social Action: aplicar-se sempre mais ao estudo da estrutura como correlação entre agência, interpretação e subjetividade, em especial, concentrar-se no tema dos significados como elementos moral-normativos capacitados a coordenar, orientando as atitudes individuais.

Sem dúvida, Parsons guarda da obra de 1937 a proposição de que Weber e Durkheim compartilham de um mesmo horizonte pois ambos, ao falarem, respectivamente, em legitimidade e autoridade, estariam enunciando conceitualmente a devoção a valores que superariam os limites dos interesses da autoconservação individual e inserindo estes mesmos interesses nos planos da entrega a ideários, cuja abrangência só a teoria coletivista de prisma macrossociológico voltado à escala dos sistemas poderia dar conta. Ao mesmo tempo, isto requer aliar, ao problema cognoscitivo da realização instrumental de finalidade, a questão da norma e, com ela, tudo que cerca o tema mesmo do envolvimento, notadamente a evocação afetiva. Assim, o autor resgata a contribuição psicanalítica, principalmente as elaborações canônicas de Freud, quando escreve o livro Social Structure and Personality.

Editado em 1964, na verdade a obra compila, em três partes, um rol de artigos teóricos e analítico-empíricos que revelam a trajetória parsoniana ao longo da década de 1950, período de maior aproximação com a psicanálise. Em especial, a primeira parte demonstra o esforço de oferecer uma perspectiva teórica. Neste sentido, o artigo de abertura - "The superego and the theory of social systems" - reúne as principais sugestões ao tipo de aporte conceitual que o autor canaliza para interpretação da relação entre as dimensões psíquico-biológicas e societais. Inicialmente, Parsons se debruçou na maneira como Freud resolve, pelo emprego das categorias de "catexia" e de "identificação", a relação sujeito e objeto na teoria do superego. De acordo com a proposição freudiana, a instância superegoica do inconsciente é formada, ante de mais nada, pela catexia (ou seja, por afetos, amor). O que leva o sujeito a identificar-se ao seu objeto seria o amor, permitindo a internalização do último. As crianças concentradas em seus pais, como fonte de prazer, os introjetariam afetivamente, identificandose a eles e convertendo os traços inerentes às personalidades dos 
pais em seus elementos psíquicos. Justamente o interesse de Parsons pela psicanálise é a possibilidade que esta ofereceria de demonstrar como, no movimento formativo da personalidade, as condições externas são sempre mais mediadas por padrões morais internalizados. A expensas de Freud, ele extrai uma plataforma explicativa à internalização das normas como incorporação, ou seja, desde a tenra infância, os objetos sociais estariam referidos às interações em que prevalece a conexão entre afetos e identificações. Na proposta freudiana, ao se deflagrar na primeira internalização objetual a formação do superego, dar-se-ia o trato com outras modalidades de autoridade ao longo da vida pessoal. Parsons conclui, alargando por conta própria e fazendo a crítica da concepção original freudiana, que toda e qualquer relação com objetos externos seria regulada por padrões normativos previamente internalizados.

Com isto, argumenta Parsons, a relação com os objetos é experienciada pelos sujeitos como se fosse familiar, deslocando a percepção de externalidade daqueles. Nesta interpretação, ressaltase o foco do interesse parsoniano: demonstrar que, na generalização da infância, os movimentos de introjeção e identificação compõem não apenas a formação da personalidade, igualmente da manutenção da sociedade. Deste modo, o autor acrescenta que a distinção entre sistema cultural, social e de personalidade é tão somente analítica, não se trataria de substâncias, entes físicos, afinal uma instituição, uma situação social e uma pessoa constituem simultaneamente todos os sistemas.

Com tal esclarecimento, o autor define personalidade como o conjunto das necessidades individuais (orgânicas e emocionais) que assume um perfil em cada indivíduo por meio da socialização, ou melhor, da evolução da sua experiência no escopo da sociedade. A personalidade é um nível da vida social articulado, mas não redutível à diferenciação social. Já o nível do sistema social é aquele das interdependências das personalidades, em que a organização societal enfrenta a distribuição de bens em meio à escassez de recursos exigidos à satisfação das diversas necessidades individuais, assim, inserindo os temas da legitimidade e da justiça. A cultura interfere justamente por fornecer amplos padrões simbólicos de sentido e valor, que informam de ideais o ajuste possível entre as necessidades e a sistemática das interações. Logo, a cultura estaria na raiz da possibilidade de entender o sistema social como uma série complicada de papéis sociais, definidos como um conjunto detalhado de obrigações para a interação no mundo real. Vemos, assim, que a sequência de papéis executados por um ator encadearia sua autoimagem com as perspectivas do sistema social, já que este corresponde à coordenação e controle dos diversos papéis e, em última instância, efetuaria o controle das necessidades à base dos valores comuns difundidos. A coerência sistêmica seria, portanto, um produto caracterizado pelo estado pleno de equilíbrio e cooperação entre as 
partes. Esta harmonia se regularizaria pela complementaridade das expectativas intrínsecas às institucionalizações, no bojo da quais a situação das interações diria respeito ao fato de existir mutualidade entre os desejos pela concordância entre as autoimagens, por intermédio de recompensas possíveis pela regulação dos fluxos de informação e de energias por intervenção dos meios de intercâmbio. O conflito emergiria no instante em que se tornam insatisfatórios os intercâmbios entre atores (seja de indivíduos, seja de grupos), favorecendo, assim, comportamentos desviantes aos padrões ideais descritos pelas normas.

Notoriamente, Parsons perseverava na tônica comunitarista com a sua ênfase no paradigma estrutural-funcionalista à contramão de perspectivas orientadas para o plano micro da ação e, na contrapartida, desloca o foco do desvio comportamental para soluções internas aos arranjos sistêmicos. Sem dúvida, aqui se concentram as maiores dificuldades do corpo de proposições gerais que conformam o sistema teórico parsoniano, já que toda perspectiva evolucionária em Parsons se encerra no movimento de um ordenamento de poder capacitado a maximizar as recompensas com finalidade de manter o equilíbrio entre as partes e favorecer a estabilidade mantenedora das complementaridades institucionais de todo o sistema.

Como veremos, à contramão se levantaram muitas vozes no interior da teorização sociológica, perseverando o que ficou definido como o "retorno do sujeito". Contudo, no tocante ao tema dos a priori sociais, se a contribuição parsoniana não excedeu os limites da filosofia da consciência, arraigada à concepção cognoscitivista e moral atenta à intencionalidade da agência, deixou por rastros o aprofundamento da relação entre estrutura social e psique, concebendo esta última pela óptica dos sentimentos. Em lugar apenas de ratificar a intervenção civilizatória da cultura atuando no refreio de uma natureza, ele acena à especificidade da biologia humana na medida em que esta se torna propicia a acolher a modulação normativa. Os contornos de uma teoria social das condições de possibilidades do ser e do agir estão insinuados à espera de desdobramentos construtivistas da ideia de vontade (FARIAS, 2013, p.12-13).

\section{Formas de vida no anverso de linguagens}

Por volta da década de 1960, com a recusa do modelo parsoniano, observam-se esforços de reorientações conceituações na teoria sociológica nas quais a precedência dos modelos analíticos que priorizam a manipulação do mundo é, cada vez mais, substituída por aqueles cuja tônica está posta nas abordagens movidas pela compreensão. Para as últimas, segundo Giddens, em questão permaneciam dois teores diferentes de objeto de conhecimento: se a humanidade pertence à natureza, no entanto ela lhe escapa em sua amplitude; bem outra é a situação quando o tema é a sociedade, pois esta é “(...) criada e recriada novamente, 
22 Schutz (1979, p.53-78) tem afinidades com $\mathrm{o}$ legado fenomenológico de Husserl, priorizando o ponto de vista da redução egóica do conhecimento; inspirado em Wittgenstein, Winch concede primazia ao conhecimento, mesmo do eu, fundado sobre o repertório semântico publicamente veiculado (WINCH, 1970, p.13-46). ainda que ex nihilo, pelos participantes de cada encontro social. A produção da sociedade é um trabalho qualificado, mantido e 'provocado' pelos seres humanos” (GIDDENS, 1978, p.15). Desde a década de 1960, as correntes fenomenológicas ou os desenvolvimentos da filosofia da linguagem expuseram a crítica do objetivismo que degradaria o saber e a competência compreensiva da pessoa comum. Lembra o sociólogo inglês que as contribuições de Alfred Schutz e Peter Winch, apesar das perspectivas diferenciadas, em virtude das fontes filosóficas igualmente distintas ${ }^{22}$, cotejam a mesma prerrogativa:

(...) ao formular descrições da conduta social, o cientista social, quando faz suas observações deve depender das tipificações, nos termos de Schutz, usadas pelos próprios membros da sociedade para descrever ou explicar suas ações; e cada um, de diferentes maneiras, sublinha a importância da reflexividade ou autoconhecimento na conduta humana. (GIDDENS, 1978, p.17)

Nota Giddens que a confluência assinalada nessas matrizes teórico-analíticas revela semelhantes fragilidades, ao tentar minimizar os efeitos do objetivismo intelectualista nos estudos das ciências sociais. A mais evidente faz chocar as regras que governam as distintas "formas de vida", encapsuladas nas práticas, que fazem da linguagem não apenas um código autorreferido, com as condições nas quais as pessoas se mostram capazes de perceber, pensar e, mesmo, participar das alterações nas próprias "formas de vida” da qual são participantes. Ou seja, permaneceriam anódinas questões cruciais à problemática sociológica, a saber, os problemas da mudança institucional e da mediação entre diferentes culturas. A atenção de Giddens está atraída, então, à maneira como, ao se pôr o acento nos "universos de significado discretos", não se deixam as ciências sociais refém de um relativismo incapacitado a elucidar temas como o da transformação e da comunicação interculturais. Sem abandonar as referências teórico-filosóficas que sustentam um distanciamento do objetivismo, o autor sugere que, apesar da ocorrência de alterações repentinas, o "membro comum da sociedade se move bastante rotineiramente, entre diferentes ordens de linguagem e atividade (...).” (GIDDENS, 1978, p.19)

A aposta de Giddens é reinserir o tema da consciência na cena da teoria social, porém, depurando-o dos incômodos solipsistas, ou seja, desvencilhando a teorização sociológica do apelo que enxerga a questão da reflexão-sensibilidade como mero voluntarismo, apenas apreciável pelas tendências filosóficometafísicas, logo pré-científicas do conhecimento. Explicitando sua dívida com Dilthey e Weber, insiste Giddens em assegurar que a compreensão vai bem além de um método para lidar com a incomensurabilidade do outro, mas é a "própria condição ontológica da vida humana na sociedade como tal" (GIDDENS, 1978, p.19). A intenção, portanto, não se reduz à clausura das idiossincrasias individuais; corresponde às conexões entre aportes biológicos e psíquicos com categorias comunicativas que se desvendam à luz de específicas formas de vida:

Entender o que uma pessoa faz só é possível pela compreensão, isto é, pela capacidade de descrever o que os 
outros fazem, e vice-versa. Mais do que um problema de empatia, é uma questão de semântica; e a reflexividade, como propriedade distintiva da espécie humana, é íntima e integralmente dependente do caráter social da linguagem. (GIDDENS, 1978, p.19)

Os termos propostos para o construtivismo fazem dueto com o fato de a linguagem ocupar cada vez mais um lugar peremptório na análise sociológica. Ainda nas trilhas do relato de Giddens, o impacto advém do fato de que a ontologia da linguagem resiste à redução de ser apenas um sistema simbólico, ainda que se defina pela potencialidade de proporcionar enquadramentos para o mundo. Como atividade social e, como tal, realiza-se no social, simultaneamente a linguagem atuaria para estender as reciprocidades humanas, embora esteja sujeita às demais implicações do contexto de uso e significação por parte das pessoas. De acordo com o modelo estruturacionista, entende Giddens (1989) que o problema em torno da constituição da sociedade é reinserido na duplicidade com que os agentes da sociedade a constituem na dinâmica da produção deles pelas condições coletivas. Posto deste modo, ele rejeita a premissa de tratar o tema da ação e dos ideais motivadores sem que se considerem, também, as assimetrias de poder e as divisões de interesse na sociedade. Isto é, para acessar a concretude da ação, três aspectos da interação deveriam ser observados: a constituição do significado, a moralidade e as relações de poder. Assim, o autor chama atenção ao fato de que as escolhas e as objetivações dos posicionamentos humanos não ocorrem em um vácuo. $\mathrm{O}$ que, exatamente, torna viável que a atitude de alguém se faça singular àquela pessoa é que o gesto seja reconhecível pelo repertório de saberes de outros. Repertório que, logo, é intrínseco à ação do primeiro e baseia a sua significação, mas que também é transcendente àquela pessoa em específico, ou a todas envolvidas na interação, equivalendo a uma instituição, cujo acesso depende das possibilidades, ou melhor, do modo como estão distribuídos os recursos da sociedade. Por isto, Giddens emprega o conceito de "dualidade estrutural" para sintetizar a ideia de que "as estruturas aparecem tanto como condição e como consequência da produção da interação" (GIDDENS, 1989, p.01-31).

A sequência dos passos sintetizados por Giddens deixa entrever uma transformação paradigmática importante, pois atinge a apreensão das ontologias sócio-históricas e do plano não empírico, quer dizer valorativo, da sociologia. Para Jeffrey Alexander, o panorama mais contemporâneo da teoria social é favorável à emergência de um "novo paradigma teórico", o qual denomina "cultural" e que estaria em dívida com as contribuições filosóficas de Michel Foucault e Jürgen Habermas. Isto porque, à luz das intervenções epistemológicas de um e outro autor, no discurso sociológico seria baixo o grau de homogeneidade capaz de mascarar as contingências empíricas. De acordo ainda com Alexander, na medida em que são "discursos à procura da verdade", o coeficiente baixo de unidade os leva a ingressar em um estágio reflexivo "sobre como a verdade pode ser alcançada e o que 
vem a ser essa verdade" (ALEXANDER, 1987). E, se as ciências sociais compreendem um campo discursivo, igualmente está atravessado pela sistemática tentativa de "identificar tipos de argumentação e critérios de obter uma justificação convincente". Logo, os discursos proferidos apontam o engate particular entre empreendimentos racionais e "reconhecimento de argumentos supra-empíricos". Concluímos estarmos na sociologia em uma esfera de competência epistemológica em que o alvo da comunicação científica são os critérios de avaliação da verdade, os quais envolvem os distintos domínios não empíricos, isto é valorativos. Algo assim impede uma apreensão apenas empiricista e acumulativa, na medida em que descortina o caráter dialógicoreflexivo, tanto do objeto, quanto do modo de produção de conhecimentos socioantropológicos.

A mútua referência estabelecida entre as intervenções habermasiana e as foucaultianas, nesta virada paradigmática, deixa ver que, se as trajetórias e as finalidades entre uma e outra vertente são, de fato, distintas, nem por isso é inoportuno anotar o quanto elas se aproximam na tentativa histórico-filosófica de colocar a racionalidade ocidental como objeto de pensamento. Em termos metodológicos, Habermas apela ao exercício da reflexividade crítico-argumentativa, apenas possível tendo por fundo comum o mundo da vida pré-reflexivo, com a finalidade de desconstruir a memória intrínseca à narrativa linear e ascendente da razão instrumental vinculada aos sistemas do poder e do dinheiro. Já Foucault debruça-se sobre a reciprocidade entre domínios de saber, tipos de normatividade e formas de subjetividade na conformação da experiência em determinada cultura. No entrecruzamento de ambas as perspectivas, encontram-se alternativas de interpelar o social com um olhar genealógico-arqueológico com o fim de penetrar aquilo disposto como dado na superfície dos acordos. Os dois modelos buscam a historicidade no dado consensualizado pelos usos de conhecimentos embutidos em instâncias mnemônicas especificas e que, na indissociável triangulação entre pensamento, linguagem e ação (escolha/valoração), realizam a integração simbólica no ajuste das microssituações com os planos intergeracional e macrossociológico. Neste sentido, é cabível supor que o tema dos a priori sociais conhece um significativo remanejamento conceitual e empírico, agora já não mais enclausurado nas fronteiras da consciência. Por outro lado, os dois autores são acanhados quando se trata de perscrutar os mecanismos de modelação dos impulsos humanos por (em) racionalidades. Ir adiante do manto espiritualista também inclui a premissa de que os enfrentamentos entre as tantas molduras normativas (com suas respectivas imagens de mundo) se dão nos usos das linguagens cotidianas, quer dizer, nas performances discursivas mediante as quais as respectivas narrativas apresentam formas de vida específicas que concorrem entre si por deliberar a favor de uma economia de emoção também própria. 
A seguir, faremos uma breve exposição do que estamos definindo como reposicionamento da problemática dos a priori sociais diante do equacionamento da ideia de linguagem à luz, tanto da premissa do significado, como uso, quanto da concepção de formas de vida.

Um primeiro aspecto a ser ressaltado: não se trata de reter apenas nas manifestações simbólico-comunicativas sintaxes, pretendendo ir às regras subjacentes a todo o aprendizado e ao pensamento; regras, as quais habilitam o indivíduo humano à fala inovadora permanente, mas consistente e adequada aos contextos de interlocução, não circunscrita aos determinantes do estímulo. Ou seja, escapa-nos o que o linguista Noam Chomsky a certa altura denominou de "gramática universal", modelo com o qual pretende entender os princípios determinantes da formalidade reguladora da língua, que corresponderia à busca da "natureza das faculdades humanas" (CHOMSKY, 1971, p.44-45). Se, igualmente, não são centrais os sistemas linguísticos responsáveis (quando interiorizados por uma pessoa) pela maneira particular de relacionar sons e significados - o que Chomsky denomina de "gramática particular" -, a ideia de código linguístico tampouco desempenha um papel decisivo na discussão dos a priori sociais. Predicando a existência de um incontornável "repertório de 'possibilidades preconcebidas"” para qualquer comunicação, o também linguista Roman Jakobson advoga a coalescência entre a lógica linguística e da linguagem, justamente enfatizando a concepção herdada da engenharia da informação, em que código e mensagem são plenos equipamentos teóricos para lidar com a interlocução humana, e esta também se traduziria na polaridade emissor decodificador, estando ambos compartilhando de um mesmo sistema fonológico. Segundo o mesmo autor russo, este último repercute na competência dos falantes, já que, pelo fato de a linguagem requerer escolha e articulação, o sistema agiria na seleção de unidades linguísticas e "sua combinação em unidades lingüísticas de mais alto grau de complexidade" (JAKOBSON, s.d., p.37). Logo, estabelecer-se-ia uma expectativa no momento em que o emissor da mensagem faz uma escolha no elenco de "representações pré-fabricadas", tanto supondo, quanto exigindo ao receptor determinada escolha também coerente com o mesmo "arquivo".

Para justificar em que medida a tônica mais estrutural é preterida na acepção do nexo entre linguagem, conhecimento e categorias do entendimento, aqui desenvolvida, passamos a descrever o ponto de partida teórico adotado, o qual tem por núcleo filosófico certa perspectiva encontrada em Wittgenstein. Desde logo é urgente sublinhar: não é nossa intenção abarcar as complexas reflexões do autor sobre a linguagem. Trata-se, isto sim, de uma investida tangencial, com vistas a privilegiar as ideias de “jogo de linguagem" e "formas de vida". Em relação à primeira, o que nos é palpitante decorre da iniciativa do filósofo austríaco de ressaltar a analogia entre jogo e linguagem, na inversamente 
simétrica proporção do afastamento em relação à concepção da linguagem como cálculo. Assim, descolando o "significado" dos signos de uma subordinação representativa, interessa-lhe o significado de uma manifestação como o somatório das regras que determinam os "lances" possíveis. Com isto, a determinação corresponde à aplicabilidade, ou seja, o modo como as linguagens interagem com outras atividades linguísticas e não linguísticas. As regras, porém, não antecipam precisamente o sucesso, mas circunscrevem o que é certo ou errado em relação a um desempenho. Portanto, o aprendizado dos significados advém do processo mesmo de aprendizagem da maneira de proceder nas condições possíveis de praticar, aí onde se define o aceitável, e é descartado o ininteligível. As regras deixam de comparecer, logo, à maneira do demiurgo rígido, capaz de homogeneizar a aparência múltipla e inconstante da linguagem (GLOCK, 1998, p.225-226).

A respeito do tema, em Investigações Filosóficas, Wittgenstein incita-nos, no parágrafo 247 , a ter em conta os "liames de ensino", isto é, o fato básico da existência de regras que delineiam e são delineadas nos usos pessoais de uma linguagem (PEARS, 1973, p.162-163): "Somos talvez precipitados ao supor que o sorriso do bebê não é simulação? - E em que experiência se baseia nossa suposição? (Mentir é um jogo de linguagem que deve ser aprendido como qualquer outro)". Outra vez, no parágrafo 363 da mesma obra, ele convoca a atenção para a linguagem como prática, ou seja, ao significado como um lance situado
Quando me represento algo, então acontece com certeza alguma coisa? Ora, acontece alguma coisa - e por que faço barulho? Certamente para comunicar o que acontece. - Mas de que modo comunicamos alguma coisa? Quando dizemos que algo foi comunicado? Qual o jogo da linguagem do comunicar?

Diria: "Você considera extremamente óbvio que alguém possa comunicar alguma coisa". Isto é, estamos tão acostumados com a comunicação através da fala, em conversa, que nos parece que todo o essencial da comunicação reside no fato de um outro apreender o sentido de minhas palavras - algo anímico -, de recebê-lo, por assim dizer, no seu espírito. Quando ele, além disso, faz alguma coisa com elas, isto então não pertence mais à finalidade imediata da linguagem.

Diríamos: "A comunicação faz com que ele saiba que eu tenho dores; ela causa este fenômeno espiritual; tudo o demais é inessencial na comunicação". A respeito deste estranho fenômeno do saber, não nos precipitemos. Processos anímicos são mesmos estranhos. (É como se disséssemos: "O relógio nos mostra as horas. $O$ que é o tempo não está ainda decidido. E para que lemos o tempo isso não cabe tratar aqui”). (WITTGENSTEIN, 1979, p.95).

Sabemos o quanto a vertente defendida por Wittgenstein na proposta de jogos de linguagem altera a fundo a ideia mesma de significado, pois são descartadas, tanto as "constantes lógicas" como substitutas de coisas, quanto a oposição entre nomes e proposições. Para o autor, o significado de um signo, quer dizer, um nome, advém do êxito de um uso que o correlacionou a uma situação, a um objeto. A confluência entre enunciado (sempre parcial) e treinamento prevalece em detrimento da ideia de correspondência entre significado e objeto, elucidando a linguagem como um fluxo de ajustes. 
Ingressamos, assim, no terreno movediço dos "mundos possíveis", em que as representações são instáveis por causa da coerção de adequar-se às interlocuções; as representações se performatizam no desempenho, na busca da finalidade de aperfeiçoar a função comunicativa, no movimento de alteração das regras dos jogos de linguagem. A operação da linguagem não está presidida pela verificação de um critério de verdade na expressão, mas na tônica depositada na expressão como definida pela prática da regra, entendendo a última por signos descritivos da própria significação. Vimos que as regras são ordens para as quais somos treinados a seguir pelo aprendizado de jogar. Logo, a realidade dos “mundos possíveis" diz respeito às várias molduras que derivam da deformação de outras pela flutuação dos usos, enfim, pela linguagem como algo no mundo realizado, mas isto no compasso mesmo de se concretizar uma atividade, entre outras. Na trilha desse pragmatismo, portanto, a ideia de "forma de vida" entrelaça cultura, visão de mundo e linguagem. Isto porque, ao tomar esta última como atividade, implica considerar o emaranhado das funções sociais imerso nas práticas de significação e, simultaneamente, sabendo que tais funções são constitutivas dessas significações. Ora, por isso mesmo, as formas de vida são os elementos "dados" da linguagem, compõem a estabilidade proporcionada pelo espaço lógico disposto no anverso do flutuar dos lances e, ao mesmo tempo, este ponto, a princípio transcendental, contrasta com a concepção de que, inscritas nas atividades humanas (e só deste modo podem reivindicar existência e validade), as gramáticas estão sujeitas às marolas nas alterações provocadas na e de acordo com a natureza antropológica humana, ou seja, de criaturas de linguagem caracterizadas pelo exercício histórico-cultural de comandar, perguntar, falar, medir, narrar. Podemos concluir então que, por se constituírem em "dados", as formas de vida são, concomitantemente, indeterminações e determinações. Múltiplas, pois são as transformações de outras molduras por obra dos usos, também se impõem de maneira contingente aos agentes-usuários da compreensibilidade, tecida em específica forma de vida, a ponto de terem, os últimos, os olhos cerrados à compreensão de outras formas de vida.

Os argumentos de Wittgenstein alinham dois aspectos que nos parecem cruciais a serem perscrutados, no estudo sociológico dos a priori, como esquemas signo-perceptivos aptos a instaurar mundos possíveis à inteligibilidade, comunicação e compreensão. Primeiro, estando aliada com a análise das técnicas de discurso devotada às redes de poderes que, na sociedade, atuam sobre a produção discursiva, a qual é assim controlada, "selecionada, organizada e redistribuída por certo número de procedimentos que têm por função conjurar seus poderes e perigos, dominar seu acontecimento aleatório, esquivar sua pesada e temível materialidade" (FOUCAULT, 1998, p.08-09), interessa-nos a característica das linguagens como uso, em especial a especificidade dos usos que se definem práticas dotadas da 
prerrogativa de dizer as demais práticas e, com isto, de significálas. Desde já, está suscitada a questão: em quais condições tal significação da linguagem (ou das linguagens) se dá? A problematização apresentada comparece, seja em uma angulação histórico-universal, seja no escopo etnográfico das distintas possibilidades de "fala", o que conduz, assim, à maneira como um modo de falar se realiza conjuntamente às suas categorias do entendimento. O segundo aspecto vem embutido no anterior, já que a pergunta pelas condições de possibilidade da significação da linguagem como prática habilitada a significar outras faz interferir a composição processual das interdependências sociofuncionais, ou seja, o jogo de forças inerente a uma moldura, às regras de uma forma de vida e aos fatores de sua transformação. Ambos os aspectos nos realinham no debate sobre o tema dos a priori na medida em que se ater aos domínios do recordar e do esquecer é recorrer aos patrimônios portadores da experiência simbolicamente armazenada, naturalizada como hábitos e gestos. Impreterivelmente, algo assim requer debruçar sobre os meandros dos tipos de incorporação possíveis no andamento mesmo de aprendizado de uma língua e como esta sedimentou um marco para outras linguagens, embora não as substitua, tampouco sua hegemonia esteja resolvida em uma arquitetura funcional, estando esta acossada pelos atravessamentos e desconcertos conflituosos.

Ao entender como importantes passos nesse descentramento espiritual na teoria sociológica, porque se priorizam os dispositivos de regulação e coordenação das pulsões biopsíquicas, para encerrar esta exposição iremos abordar, nos respectivos esquemas de Pierre Bourdieu e Norbert Elias, as considerações à proposta de relacionar o tema das disposições de regulação dos atos corpóreos à junção de memória, linguagem e conhecimento. Os dois autores são, a nosso ver, expressões da tônica pluridisciplinar depositada nos aportes multimodais, o qual tem por objeto a economia unificada das práticas e dos símbolos, cujo fundamento ontológico está na unidade entre sujeito e objeto.

\section{Incorporação e mimesis nas competências de ser}

Neste item, o trajeto consistirá no cotejo transversal das respectivas contribuições de Bourdieu e Elias a uma sociologia da linguagem e do simbólico, pois entendemos que há complementaridade entre as formulações de ambos os autores no tocante à compreensão da convergência das condições bioevolutivas e histórico-universais com o plano das correlações institucionais que estruturam as linguagens como práticas habilitadas a significar outras práticas. Isto quer dizer que as linguagens estão autorizadas a tornar as demais práticas expressivas, ao mesmo tempo em que são compreensivas aos seus realizadores, mas aptas às trocas públicas de sentido. Ainda, no saldo das duas inferências, uma conclusão possível diz respeito ao lugar dúbio ocupado pela dimensão sociodiscursiva, já que a 
condição do "dizer" requer a participação, a integração em uma correlação que é, concomitantemente, aliança interativa e disposição assimétrica, definida pelas posições em um arranjo de poder simbólico. E, por isso mesmo, o significar é simultaneamente reprodução, mas, também, abertura, porque dizer demanda aprendizado, e aprender, lembrar, pensar, emitir e se fazer entender exigem reciprocidade contemporânea e encadeamento geracional, da qual somos depositários e mediadores, mas igualmente intérpretes, e não simplesmente exegetas ou porta-vozes. Afinal, o transporte do significado requer a singularidade do desempenho que o realiza no ato expressivo, o qual está espreitado pela censura ou pelo equívoco. A narrativa está no interstício da expressão com a mimese; contar uma história depende de uma história contada, ou seja, de uma anterior apresentação do mundo, com sua respectiva moldura e horizonte; da mesma maneira, uma história é inseparável daquele que a apresenta nas condições contingenciais da apresentação, logo a experiência é indissociável da incorporação de saberes intergeracionais.

No rastro da concepção fenomenológica, a experiência pode ser compreendida como o corte que interrompe a continuidade opaca na sucessão de impulsos e permite redefinir a vivência como dotada de entendimento, como algo particular em seu acontecer. Trata-se assim, igualmente, de um exercício de conhecimento não propriamente de reflexão, mas do conhecimento que apenas se torna possível em razão da intervenção seletiva das mediações cognitivas e valorativas, em uma situação de significados, modalizados por grades taxonômicas que ordenam coisas e práticas. Tais significados, por sua vez, estão conformados na memória pela interação simbólica com outros saberes e pessoas, mas, também, consorciados com as forças coletivas, institucionalizadas pela intervenção das ritualizações permanentes, inserindo-nos no escopo das classificações e das cosmologias fundamentais ao modo como priorizamos algo no real, parcelado significativamente. Isto se faz quando são subjetivamente acionados os significados na tarefa de perceber, interpretar e dar contiguidade à conduta e familiaridade ao entorno. Ora, tal acionamento é indissociável das condições históricas, nas quais são (ou não) atualizados, tanto os esquemas de nomeação e classificação, quanto os mecanismos de expressão nas reciprocidades e nos conflitos entre as pessoas.

Por certo, as bases do problema relativo ao enlace conhecimento e redes sociais, no tocante às questões de reprodução e mudança social, estão nas formulações de August Comte a respeito do enfileiramento dos quadros mentais de uma época com os grupos a eles identificados e às alterações ordenadas das formas de percepção e compreensão, ao longo do que o autor delimita como os três grandes estágios da evolução humana (COMTE, 1978, p.41-94). No entanto, a inspiração para a discussão aqui advém da questão posta por Pierre Bourdieu, ao indagar como uma atividade histórico-discursiva - no caso, a ciência -, reivindica e, 
${ }^{23}$ Para uma discussão sobre o emprego das concepções de Wittgenstein na sociologia da ciência, ver Bourdieu (2002). em certa medida, adquire status transhistórico. Em um primeiro momento, o sociólogo francês sinaliza a operação dos filósofos de se constituírem como agentes racionais das verdades eternas:

Em resposta à questão de saber qual é o 'sujeito' desta 'criação de verdades e de valores eternos', pode-se invocar Deus ou tal dos seus substitutos, dos quais os filósofos inventaram toda uma série: é a solução cartesiana dos semina scientiae, as sementes ou os germes da ciência que serão depositadas sob a forma de princípios inatos no espírito humano; ou a solução kantiana, a consciência transcendental, o universo das condições necessárias do conhecimento que são co-substanciais ao pensar, o sujeito transcendental era de qualquer sorte o lugar das verdades $a$ priori que são o princípio de construção de toda verdade. (...). (BOURDIEU, 2001, p.10 - minha tradução).

Bourdieu interroga historicamente as gramáticas do conhecimento, compreendendo-as nas cooperações e lutas pela imputação do nome e dos sentidos legítimos da ciência, mas sem abrir mão da especificidade desse campo social em estabelecer uma dinâmica fundada na busca da verdade, na universalidade. De clara inspiração wittgensteiniana ${ }^{23}$, o autor deixa margens não apenas para o estudo das condições sociais do conhecimento, mas permite, também, avançar sobre os efeitos sociais do conhecimento na montagem dos mundos possíveis postos nas próprias interações sociossimbólicas, com seus limites de expressão e comunicação. Os esforços analíticos de Bourdieu sublinham o exercício de explicitar tanto os esquemas transmitidos quanto os esquemas empregados na transmissão, atentando ao fato de que as regras são feitas de pessoas, e não apenas por estas, pois entende que os esquemas perceptuais e valorativos contêm a correspondência entre a estrutura social e as estruturas mentais, entre as divisões objetivas do mundo social, sobretudo entre dominados e dominantes nos diferentes campos, e os princípios de divisão que os agentes aplicam. Desse modo, o autor destaca o esforço sociológico de forçar a descoberta da "exterioridade no coração da interioridade, a banalidade na ilusão da raridade, o comum na pesquisa do único", não apenas "para efeito de denunciar todas as imposturas do egoísmo narcísico”, mas principalmente por “(...) oferecer um meio, ainda que único, de contribuir, talvez pela consciência das determinações, à construção de algo como o sujeito, de um modo geral abandonado às forças do mundo" (BOURDIEU, 1980, p.4041).

Sintetizando as contribuições da Escola francesa (a partir de Durkheim e Mauss), mas amalgamando-as com as elaborações de Marx e Weber na concepção de universo social, dois planos se relacionam de maneira homóloga: a "objetividade de primeira ordem", quer dizer, a condição oriunda da distribuição dos recursos materiais e os meios de apropriação dos bens e dos valores socialmente raros (“capitais"); e a "objetividade de segunda ordem", compreendendo os esquemas mentais e corporais como matrizes simbólicas das atividades de práticas, condutas, pensamentos e julgamentos dos agentes sociais. Os fatos sociais são, logo, as significações que os seres humanos dão ao mundo por 
eles construído (WACQUANT, 1992, p.16-17). Utilizando o trocadilho de que lança mão o autor, visando, por sua vez, criticar Marx (embora nele se inspirando), interessa-lhe apreender as "coisas da lógica" na "lógica das coisas", isto é, realizar a interpelação sociológica da razão, que passa pelo exercício de descortinar as condições de possibilidade não apenas da razão científica, mas, também, de todas as racionalidades ou, se quisermos, de específicas linhas de conduta autorreferidas aos seus núcleos de interação, aquilo denominado "campo", de acordo com o seu próprio jargão. Assim, Bourdieu retorna à combinação de duas questões intelectuais fundamentais às preocupações weberianas, a saber, a imputação do sentido legítimo e as distinções sutis do mundo social.

Vale lembrar que, em Bourdieu (2009, p.86-163), uma "teoria da práxis" ou a teoria da lógica da prática corresponde ao desconforto do autor, seja ante o primado interacionista, que desvencilha a relacionalidade intersubjetiva de toda e qualquer objetividade, seja em face ao viés estrutural-cognoscitivista com sua premissa de construtos a priori de inteligibilidade, que se impõe às práticas na característica de atualizar as formas-modelos, isto é, as estruturas "estruturantes". Na contramão de outra vertente da teoria social, Bourdieu reivindica um conhecimento fundado na prática, ou seja, é-lhe decisivo compreender o "operador prático", para, com isso, averiguar as condições e os resultados das disposições duradouras que propiciam regularidade nos atos humanos. A essas disposições adquiridas - mediante, óbvio, um conhecimento adquirido -, ele denomina "habitus" (ou razão prática ou prática lógica) com a finalidade de compreender os...

$$
\begin{aligned}
& \text { (...) princípios de geração e estruturação das práticas e de } \\
& \text { representações que podem ser objetivamente 'reguladas' e } \\
& \text { 'regulares' sem nada serem o produto da obediência a regras, } \\
& \text { objetivamente adaptadas ao seu fim sem suporem a mira } \\
& \text { consciente dos fins e o domínio expresso das operações necessárias } \\
& \text { para os atingir, e sendo tudo isto, coletivamente orquestrada sem } \\
& \text { serem o produto da ação organizadora de um maestro de orquestra } \\
& \text { (BOURDIEU, 2002, p.164). }
\end{aligned}
$$

Portanto, na esteira de Marcel Mauss - ou, se quisermos, de uma apreensão original e seletiva da premissa sobre a cumplicidade ontológica com o mundo presente em Heidegger e Merleau-Ponty -, interessa a Bourdieu o habitus como corpo, e este, como história, relação social naturalizada à maneira de certezas práticas. A seu ver, a relação de posse com o mundo social é decorrente da natureza mesma da ação histórica, na qual dois estados sociais estariam em presença, quer dizer, a história em seu estado, objetivado, e a história como saber incorporado (BOURDIEU, 2001, p. 157-198). O habitus com isto consiste em um produto de aquisição histórica que, por sua vez, viabiliza a apropriação do adquirido historicamente; o destino social de um agente encadeiase aos investimentos nessa aquisição que se decalca em sua potencialidade de agir, realizar estratégias: "Podemos compreender que o ser social é aquilo que foi; mas também que 
aquilo que uma vez foi ficou para sempre inscrito não só na história, o que é óbvio, mas também no ser social, nas coisas e nos corpos." (BOURDIEU, 2002, p.100).

Não resta dúvida quanto à posição estratégica ocupada pela questão mnemônica no quadro teórico-analítico do autor Respaldada na proposição bourdiana acerca do "senso prático" na problemática do saber pelo corpo, a interpelação dos a priori se ocupa da maneira como o entendimento humano e a compreensão social são elaborados à luz dos ajustes histórico-sociológicos entre os equilíbrios de poderes intrínsecos a certos graus de interdependências sociofuncionais e as distribuições de recursos valorizados como propriedades simbólicas e discursivo-expressivas que competem, seja para delinear arranjos intersubjetivos, seja para atender ou não a composição de imagens de mundo e autoimagens envolvidas com afetividades, mas subjetivadas como estruturas cognoscitivas.

Nesse sentido, bem exemplar é o modo como Bourdieu procura objetivar sociologicamente o esquema, por intermédio do qual se exerce a dominação linguística; a seu ver, o exercício desse poder tem por dinâmica as próprias escolhas norteadas pelo habitus. Para ele, as escolhas são realizadas desprovidas de consciência e coerção, mas por força das propensões elaboradas fora da consciência e da coerção, ainda que aquelas sejam determinações sociais. Ora, o modo como são constituídas as instruções revertidas em habitus deriva do "poder de sugestão exercido através das coisas e das pessoas"; é este o fator intrínseco à eficácia de um poder simbólico, afinal se dispõe uma propensão de reconhecimento, de unidade entre o corpo que sente e o mundoobjeto. O reconhecimento, para Bourdieu, é "extorquido" pela violência simbólica, que se faz pelo seu caráter invisível, na característica diáfana das...

(...) coações, pontuais ou duradouras, a que os dominados submetem, num esforço desesperado para alcançar a correção, consciente ou inconscientemente, os aspectos estigmatizados de sua pronúncia, de seu léxico (com todas as formas de eufemismo) e de sua sintaxe, ou então, na confusão que os faz 'ficarem sem ação', tornando-os incapazes de 'encontrar suas palavras', como se ficassem de repente expropriados de sua própria língua. (BOURDIEU, 1992, p.39)

Enfim, para Bourdieu, as práticas linguísticas encontram suas medidas em relação à prática legítima. Os usos sociais da língua devem seu valor propriamente social ao fato de se apresentarem propensos à organização em sistemas de diferenças, reproduzindo o sistema das diferenças sociais na ordem simbólica dos desvios diferenciais. Propõe, como alternativa analítica, uma sociologia estrutural da língua, cujo objeto é a relação capaz de unir sistemas estruturados de diferenças linguísticas sociologicamente pertinentes e sistemas igualmente estruturados de diferenças sociais. A seu ver, tal caminho permitirá observar que falar, como uma prática, é se apropriar de um ou outro, entre os estilos expressivos já constituídos no e pelo uso. Por esse viés, perceber- 
se-á que o lucro da distinção na troca social não advém da capacidade de falar, fundada sobre o patrimônio biológico universal; a raridade está contida na competência para fazer uso da língua legítima, tal como esta integra o patrimônio social. Lançar mão desse patrimônio é o meio possível de lograr lucros simbólicos, isto é, propiciar distinções, desvios diferenciais. Algo que, de antemão, exclui os desprovidos da competência legítima para frequentar os âmbitos sociais em que prevalece o critério do uso conspícuo; estão aqueles "condenados ao silêncio" (BOURDIEU, 1992, p.42).

Sob o ponto de vista da sociologia da língua, em Bourdieu, as discussões sobre a linguagem conduzem a definir os contextos de significação como pontos intersticiais nos quais memória e linguagem (entendendo-a como prática habilitada a significar outras práticas) se cruzam na materialidade corpórea posicionada em meio ao tramado de corpos. E a concluir, também, o quanto as formas de expressão e os meios dos quais pessoas e grupos se valem na atividade significativa adquirem importância ímpar na problemática da memória e das narrativas. O que adquire relevância teórica e analítica é o tema em torno da ideia de mimese. Afinal, interessa especular sobre o gesto que, estando inserido em um repertório de conhecimentos e nos modos possíveis de expressá-lo, no instante em que o expõe, coloca as formas e, assim, mediante a aplicação interpretativa dos mesmos estoques simbólicos de conhecimento, proporciona inteligibilidade, mas por tradução e reversão, provocando deslocamentos. Entre os desafios reservados à pesquisa e discussão em torno do tema dos a priori sociais, a questão da mimesis ocupa lugar especial, porque, em função dele, é possível considerar o entendimento como um agir, um acontecimento que instaura algo no mundo. Por um lado, deixa entrever que a linguagem não apenas exibe, mas, na sua dinâmica de tradutibilidade, é a dimensão de apresentação das coisas; por outro, reinsere a interseção do dito e do efetivo na esteira da tensão disposta na cumplicidade entre o devir e o estar, o plural e o idêntico. Ao que parece, repõe-nos ante a difícil compreensão da complementaridade estabelecida pelo gênero humano entre o verossímil e a verdade.

Sem qualquer expectativa de esvaziar as muitas faces desse problema, retomamos a interlocução estabelecida em outro momento com a teorização sobre o simbólico em Norbert Elias. No artigo "Memória, saber incorporado e linguagem no esquema de Norbert Elias" (FARIAS, 2009, p.167-215), cotejamos concomitantemente as trajetórias biográfica e intelectual desse autor, segundo a proposta de atentar ao lugar que as categorias memória e saber social incorporado ocupam no seu esquema teórico-analítico figuracional. Consideramos a concepção de teoria simbólica do conhecimento eliasiana, a qual tem por núcleo a linguagem como fator a um só tempo biopsíquico e sócio-histórico. Pareceu-nos em particular promissora a discussão acerca da noção de mimesis na medida em que, em virtude dela, a memória está na 
24 "Se perguntarmos de que modo e que se animam os sentimentos, como e que a excitação e favorecida pelas actividades de lazer, descobre-se que isso e dinamizado, habitualmente, por meio da criação de tensões. Perigo imaginário, medo ou prazer mimético, tristeza e alegria são produzidos alegria são produzidos possivelmente resolvidos no quadro dos divertimentos. Diferentes estados de espíritos são evocados e talvez colocados em contraste, como a angustia e a exaltação, agitação espírito. Deste modo, os sentimentos dinamizados numa situação imaginaria de uma actividade humana de lazer têm afinidades com os que são desencadeados em situações reais da vida - e isso que a expressão 'mimética' indica - , mas o ultimo esta associado aos riscos e perigos sem fim da frágil vida humana, enquanto $o$ primeiro sustenta, momentaneamente, o fardo de riscos e de ameaças, grandes e pequenas, que rodeia a existência humana." (ELIAS e DUNNING 1992, p. 71) contrapartida das formulações sobre o dueto saber incorporado e estruturação da conduta. Referenciado, portanto, nesse diálogo já fomentado, nos parágrafos seguintes teremos por objetivo avançar um pouco mais na correlação entre mimesis e memória.

A discussão eliasiana em torno da mimesis não repercute até agora com maior ressonância no campo das ciências sociais; sobretudo os ecos mais audíveis ocorreram na produção de autores ocupados com o tema dos esportes, em razão da forte repercussão dos trabalhos de Norbert Elias - muitos dos quais compilados no livro Em Busca da Excitação: ócio e esporte no processo civilizador, assinado em parceria com Eric Dunning - sobre a posição do lazer no tempo livre das sociedades contemporâneas mais diferenciadas (MEDEIROS, e GODOY, 2009, p. 199-214; SOUZA, STAREPRAVO e MARCHI JR., 2014, p. 429-445). Em sintonia com a teoria dos processos civilizadores (ELIAS, 1990; 1993), a acepção de atividades lúdico-miméticas nesses trabalhos se refere às funções pelas quais a "libertação das tensões" ou "recuperação do desgaste do trabalho" estão interdependentes às rotinas laborais (ELIAS e DUNNING, 1992, p.115). Como as funções lúdico-miméticas são promotoras de "excitações-jogo", elas contracenam com graus elevados de autocontrole pulsional exigidos nas sociedades pacificadas no compasso de centralização estatal, as mesmas em que as cadeias de interdependências sociofuncionais requerem sempre mais previsibilidade das condutas, logo adiando as descargas emocionais. Recuperado junto ao vocabulário aristotélico, ao lado de catarse, o conceito de mimesis não corresponde a imitação; no escopo processual dessas atividades, os fatos "reais" referidos às ameaças são reelaborados imaginativamente como sentimentos de prazer (ELIAS e DUNNING, 1992, p. 125). As diversões proporcionariam, desse modo, situações de "descontrole controlado" ${ }^{24}$. Os autores deixam entreve na funcionalidade lúdico-mimética uma alternativa histórica ao gabarito elevado de autocontrole pulsional relativo ao processo civilizador europeu ocidental, cujo advento se deu em meio às pressões afetivas geradas pelos graus de restrições inerentes às diferentes teias sociofuncionais. Em se tratando da estrutura urbano-industrial emersa em algumas das sociedadesnações, tais atividades teriam efeitos catárticos, no instante em que promovem a excitação das emoções admitidas de se serem expostas em público se aninharam nos espaços designados pelo sentido de não seriedade, à maneira do esporte e da arte, à contrapartida das exigências de maximização dos refreios civilizatórios articulados aos controles sociais relativos aos complexos conglomerados burocráticos e técnico-produtivistas:

Ate onde se pode verificar, a maioria das sociedades humanas desenvolve algumas contramedidas em oposição às tensões do stress que elas próprias criam. No caso das sociedades que atingiram um nível relativamente avançado de civilização, isto é, com relativa estabilidade e com forte necessidade de sublimação, as restrições harmoniosas e moderadas, na sua globalidade, podem ser observadas, habitualmente, numa considerável multiplicidade de actividades de lazer, que desempenham essa função, e de que o desporto é uma variante. Mas, para cumprir a função 
de libertação das tensões derivadas das pressões, esta actividades devem conformar-se a sensibilidade existente face à violência física que é característica dos hábitos sociais das pessoas no último estádio de um processo de civilização. (ELIAS e DUNNING, 1992, p. 69-70).

Embora nem sempre sob a denominação lúdico-mimética, a funcionalidade dessas atividades é, em muitos momentos, retomada como heurística na obra eliasiana, seja para tratar da "romantização" da vida campônia por parte de uma nobreza que se vê obrigada abrir mão dos ímpetos guerreiros, quando alocada nas cortes reais absolutistas (ELIAS, s.d., p.50), seja nas diferentes apropriações sentimentais do quadro A Peregrinação à Ilha do Amor, de Watteau (ELIAS, 2005, p.15-58) ou, ainda, nos dilemas existenciais e psíquicos experimentos por Mozart movido pela luta em favor do ideário de arte pura realizado no esforço de desprivatizar as "fantasias artísticas" (ELIAS, 1995, p.61-62). A respeito deste último empreendimento, o autor identifica o perigo inerente às sublimações pelas quais o fluxo libidinal elementar das fantasias é transformado pelos fluxos de conhecimentos adquiridos. A ameaça está representada na diluição da espontaneidade fantasiosa. O êxito estaria na fusão entre ambos na obra artística, aí onde o conflito que existiria, a princípio, seria dissolvido. Ora, algo assim supõe o perfil psíquico-emocional do artista nas sociedades muito diferenciadas, em que a demanda de elevado autocontrole consubstancia-se no desempenho experimental de tornar comum, logo, acessível às trocas públicas de sentido, os fluxos libidinais de fantasia (ELIAS, 1995, p.63-64)
Dois aspectos devem ser ressaltados em face dessa proposição: de um lado, a proximidade, estabelecida por Elias, nas atividades miméticas entre autocontrole, conhecimento e memória - na medida em que supõe uma tradição e sua transmissão. Com esta primeira questão, iremos encerrar este texto. Por ora, atentamos ao outro aspecto, a saber, a noção de mimesis acionada pelo autor.

Já anotamos que o significado da ideia de mimesis operacionalizada na análise eliasiana não é sinônimo de imitação, mas corresponde a um recurso ao quadro de categorias empregadas na Poética, de Aristóteles. Nesta obra, a catarse promovida pela função mimético-imaginativa ("phantasía") do teatro teria por finalidade a emoção purgativa do "pathos", ou seja, as perturbações que tomariam de assalto os homens. Nesse sentido, a catarse teria função farmacêutica. Ainda consista em uma modalidade de imagem, a mimesis desempenha um papel decisivo na teoria do conhecimento aristotélica. De acordo com a interpretação de Costa Lima (1995, p. 63-76), calcada no conceito de "forma própria" ("idia morphé"), a concepção de mimesis se equilibra entre o sensível (a imagem) e o inteligível (o conceito), compreendendo um modo de aprendizado definido pelo maravilhamento, isto é, pelo prazer sensível que não decorre da duplicação de algo, mas advém do reconhecimento do que é essencial, enfim, a mimesis apresenta por metáforas a inteligibilidade das formas imutáveis, logo se coloca a serviço da verdade, portanto cumpre a tarefa 
mnemotécnica de fomentar o não esquecimento ("alatheia") (WEINRIECH, 2001, p.19-21).

Nota-se que a referência à concepção de mimesis em Aristóteles distancia o emprego feito por Elias da semântica que grassou maior relevo na Europa após o Renascimento: desde então, prevaleceu a mimesis como sinônimo de "discurso ornado", correspondendo à mera duplicação imitativa subserviente aos costumes e, com isto, na contramão do valor atribuído ao ideário da criação (COSTA LIMA, 1995, p. 77-157). Em Elias, a mimeses prossegue relativa ao investimento simbólico realizado pelo tramado corpóreo da espécie humana em si mesmo, no trajeto histórico de longa duração em que os múltiplos usos cotidianos do próprio corpo, a um só tempo, deixaram por rastros a metamorfose da experiência em saberes acomodados nas linguagens, as quais se dispõem não só em sistemas de representações (oral-escrito, visual, audiovisual, entre outros), mas também em cortes culturais mais abrangentes. E, assim, os saberes se colocam à disposição para serem encarnados - incorporados - em novos usos que, tanto os promovem, quanto os transformam. Em última instância, solicitando a prerrogativa defendida por Nelson Goodman (2006, p.35-72), a apropriação eliasiana da mimesis a projeta como fator construtivista, um fazer pelo qual mundos são erguidos na medida mesma em que são apresentados e descritos.

Em A Teoria Simbólica, Elias (2002, p.03-08) observa serem convencionados étnico-historicamente os padrões sonoros, logo, a função de delimitar até certo ponto as possibilidades de desempenho linguístico por parte de um falante está ela mesma sob o signo do construtivismo. Por um lado, diz respeito à organização biológica da espécie pela qual indivíduos humanos detêm a faculdade de falar. Mas esta faculdade apenas é acionada mediante aprendizados proporcionados por bens culturais relativos a sociedades específicas. Se, então, o conhecimento geneticamente transmitido no andamento evolutivo da espécie é a cada novo indivíduo retomado, este mesmo legado requer, à sua efetivação, o fundo de saberes cuja elaboração e transmissão simbólica se dão em intercursos geracionais. Envolvendo os planos biológicos e psíquico-histórico-socioculturais, a visão sintética proposta por Elias elucida na presença corporal a cumplicidade daquilo nomeado por memória com as funções aprendidas de autocontrole - sendo estes os a priori sociais.

\section{Referências Bibliográficas:}

ALEXANDER, Jefrey. Las Teorias Sociológicas desde la Segunda Guerra Mundial: Análisis Multidimensional. Barcelona: Gedisa, 1988.

ALEXANDER, Jeffrey. “O Novo Movimento Teórico”. Revista Brasileira de Ciências Sociais, n. 4, julho, 1987.

ARRUDA, Ângela. "Teoria das representações sociais e ciências sociais: trânsito e atravessamentos". Sociedade e Estado, n.24 vol. 3, 2009.

ASSMANN, Aleida. Espaços da Recordação: formas e transformações da memória cultural. Campinas: Unicamp, 2011.

BENOIT, Lelita Oliveira. Sociologia Comteana: Gênese e Devir. SP: Discurso Editorial, 1999. 
BIERSACK, Alleta. "Saber local, história local: Geertz e além" In: Lynn Hunt (org.): A Nova História Cultural, 1992.

BOLLÈME, Geneviève. O Povo por Escrito. São Paulo: Martins Fontes, 1988

BOURDIEU, Pierre. O Senso Prático. Petrópolis (RJ): Vozes, 2009.

BOURDIEU, Pierre. Esboço de uma Teoria da Prática. Oeiras: Celta, 2002.

BOURDIEU, Pierre. "Wittgenstein, le sociologisme \& la science sociale". In: Jacques Bouveresse, Sandra Laugier et Jean-Jacques Rosat (orgs.): Wittgenstein: Dernieres Pensées. Marseille: Agone, 2002a.

BOURDIEU, Pierre. Science de la Science et Réflexivité. Paris: Raisons d'Agir, 2001.

BOURDIEU, Pierre. Meditações Pascalianas. RJ: Bertrand do Brasil, 2001a.

BOURDIEU, Pierre. O Poder Simbólico. RJ: Bertrand, 2000.

BOURDIEU, Pierre. A Economia das Trocas Simbólicas. SP. Perspectiva, 1992.

BUCKLEY, Walter. A Sociologia e a Moderna Teoria dos Sistemas. SP: Cultrix, 1974.

BURKE, Peter. A Escola de Annales: 1929-1989. SP: Unesp, 1991. BURKE, Peter. Formas de Hacer Historia. Madrid: Alianza, 2003. BURKE, Peter. Cultura Popular na Idade Moderna. São Paulo: Cia das Letras, 2010.

CASSIRER, Ernest. Ensaio sobre o Homem: introdução a uma filosofia da cultura humana. SP: Martins Fontes, 2005.

CERTEAU, Michel. A Cultura no Plural. Campinas: Papirus, 1995.

CHARTIER, Roger. A História Cultural: entre práticas e Representações. Lisboa: Difel, 2002.

CHARTIER, Roger. "“Cultura popular': revisitando um conceito historiográfico". Estudos Históricos, Rio de Janeiro, vol. 8, n 16 , 1995, p. 179-192.

CHOMSKY, Noam. Linguagem e Pensamento. Petrópolis (RJ): Vozes, 1971.

COMTE, August. "Discurso Sobre o Espírito Positivo" in: Os Pensadores: Comte, SP: Abril Cultural, 1978.
COSTA LIMA, Luiz. Vida e Mimesis. Rio de Janeiro: Editora 34, 1995.

DAVIS, Natalie Z. Culturas do Povo: sociedade e cultura no início da França moderna. Rio de Janeiro: Paz e Terra, 1990.

DESAN LLOYD, Christopher. As Estruturas da História. RJ: Jorge Zahar Editor, 1998

DESAN, Suzanne. "Massas, comunidade e ritual na obra de EP Thompson e Natalie Davis" In: A Nova História Cultural. São Paulo: Martins Fontes, p. 63-96, 1992.

DURAND, Gilbert. As Estruturas Antropológicas do Imaginário. SP: Martins Fontes, 2001

DURKHEIM, Emile. As Formas Elementares da Vida Religiosa. SP: Paulus, 1989.

DURKHEIM, Emile. As Regras do Método Sociológico. SP: Cia Editora Nacional, 1985.

DURKHEIM, Emile. Sociologia, Pragmatismo e Filosofia. Porto: RÉS Editorial, s.d

DESAN, Suzanne (1992.). "Massas, comunidade e ritual na obra de E.P. Thompson e Natalie Davis" In: Lynn Hunt (org.): A Nova História Cultural. SP: Martins Fontes, 1992.

ELIAS, Norbert. Teoria Simbólica. Oeiras: Ceuta, 2002.

ELIAS, Norbert. Mozart - Sociologia de um Gênio. Rio de Janeiro, Jorge Zahar, 1995.

ELIAS, Norbert. O Processo Civilizador - Formação do Estado e Civilização (v. 2). Rio de Janeiro: Zahar, 1993.

ELIAS, Norbert. "Introdução" In: ELIAS, N.; DUNNING, E. A Busca da Excitação. Lisboa: Difel, 1992, p. 39-99.

ELIAS, Norbert. O Processo Civilizador - Uma História dos Costumes. (v. 1). Rio de Janeiro: Zahar, 1990.

FARIAS, Edson. "Introdução: Estudar a metrópole a partir do seu $a$ priori" In: Edson Farias (org.): Retas que se prolongam em curvas: tensões nos usos do contexto metropolitano brasiliense. Jundiaí: Paco, 2015.

FARIAS, Edson. "Cultura e desenvolvimento: figuras históricocognitivas de uma dinâmica geopolítica". Latitude, v. 6, n. 2, 2013, pp.51-83. 
FARIAS, Edson. "Apresentação: Simbólico e linguagem entre dilemas e possibilidades socioantropológicas". Arquivos do CMD v. 1. n.1, 2013.

FARIAS, Edson. "Memória: o objeto em suas narrativas" In: Maria C. Fonseca-Silva e Edson Farias (orgs.): Memória, Discurso e Sociedade. São Carlos: Claraluz, 2012.

FARIAS, Edson. "Memória, saber incorporado e linguagem no esquema de Norbert Elias". Revista Estudos de Sociologia (UFPE), vol. 15 n.1, jan.-jun. 2009.

FOUCAULT, Michel. A Ordem do Discurso. SP: Loyola, 1998.

FOUCAULT, Michel. A Arqueologia do Saber. RJ: Forense Universitária, 2000.

GARRIDO, Margarida \& GARCIA-MARQUES, Leonel. "Em busca da distinção perdida: acessibilidade versus disponibilidade mnésicas em cognição social". Análise Psicológica, n.03 (XXI) 2003.

GIDDENS, Anthony. A Constituição da Sociedade. São Paulo: Martins Fontes, 1989

GIDDENS, Anthony. Central Problems in Social Theory. Berkeley: University of California Press, 1979.

GIDDENS, Anthony. Novas Regras do Método Sociológico. Rio de Janeiro: Zahar Editores, 1978.

GINZBURG, Carlo. O Queijo e os Vermes: o cotidiano e as ideias de um moleiro perseguido pela inquisição. São Paulo: Cia das Letras, 1987.

GLOCK, Hans-Johann. Dicionário Wittgenstein. RJ: Jorge Zahar Editor, 1998

GOFFMAN, Erving. Os Quadros da Experiência Social: uma perspectiva de análise. Petrópolis: Vozes, 2012.

GOODMAN, Nelson. Linguagens da Arte: uma abordagem a uma teoria dos símbolos. Lisboa: Gradiva, 2006

HABERMAS, Jürgen. Teoría de la Acción Comunicativa, vol. I (Cap.III "Interludio Primeiro: acción social, actividad teleológica y comunicación"). Madrid: Taurus, 1999, 2 volumes.

HABERMAS, Jürgen. O Discurso Filosófico da Modernidade. SP

Martins Fontes, 2000
HABERMAS, Jürgen. "El cambio de paradigma en Mead y Durkheim: de la actividad teleológica a la acción comunicativa" In: Teoria de la Acción Comunicativa, vol. II. Madrid: Taurus, 1999

HALBWACHS, Maurice. A Memória Coletiva. SP: Vértice, 1990 HAWTHORN, Geoffrey (1982). Iluminismo e Desespero: Uma História da Sociologia. RJ: Paz e Terra.

HONETH, Axel. Luta por Reconhecimento: A Gramática Moral dos Conflitos Sociais. SP: Editora 34, 2003.

HUNT, Lynn. "Apresentação" In: Lynn Hunt (org.): A Nova História Cultural. SP: Martins Fontes, 1992.

JAKOBSON, Roman. Lingüística e Comunicação. SP: Cultrix., s.d..

JODELET, Denise. "Le mouvement de retour vers Le sujet et l'approche des représentations sociales". Connexions, n. 89, 2008. KANDEL, Eric R. Em Busca da Memória: o nascimento de uma nova ciência da mente. SP: Cia das Letras, 2009.

KÖHNKE, Klaus. C. Surgimiento y Auge del Neokantismo. México (DF): Fundo de Cultura Econômica, 2011.

KOJEVE, Alexandre. Introdução à Leitura de Hegel. RJ Contraponto, 2002

KOSELLECK, Reinhart. Futuro Passado: contribuição à semântica dos tempos históricos. Rio de Janeiro: Contraponto; PUC- Rio, 2006.

KUPPER, Adam. The Invention of Primitive Society: transformations of an illusion. New York: Routledge, 1988.

LE GOFF, Jacques. História e Memória. Campinas: Editora da UNICAMP, 1994.

LE GOFF, Jacques \& NORA, Pierre. História: novos objetos. Rio de Janeiro : Francisco Alves, 1995.

LEVY-STRAUSS, Claude. "A análise estrutural em lingüística e antropologia" In: Antropologia Estrutural. RJ: Tempo Brasileiro, 2003.

LEVY-STRAUSS, Claude. "Prefácio" In: Sociologia e Antropologia, vol.II. SP: EPU e Edusp, 2 vol, 1974.

LUKES, Steven. Emile Durkheim: his life and work. New York: Penguin Books, 1973. 
MAUSS, Marcel. "Ensaio sobre a Dádiva" In: Sociologia Antropologia, vol.II. SP: EPU e Edusp, 2 vol, 1974.

MERLEAU-PONTY, Maurice. "De Mauss a Claude Lévi-Strauss"

In: Maurice Merleau-Ponty(Textos Selecionados). SP: Abril Cultural, 1980 (Os Pensadores).

MERLEAU-PONTY, Maurice. Fenomenologia da Percepção. São Paulo: Martins Fontes, 1999.

MEDEIROS, Cristina C. C. e GODOY, LETÍCIA. "As referências de Pierre Bourdieu e Norbert Elias na Revista Brasileira de Ciências do Esporte: mapeando tendências de apropriação e de produção de conhecimento na área da educação física" (19792007). Rev. Bras. Cienc. Esporte, Campinas, v. 30, n. 2, p. 199 214, jan. 2009.

MOSCOVICI, Serge. Representações sociais: investigações em psicologia social. Petrópolis (RJ): Vozes, 2004.

OLIVEIRA, Luis Roberto Cardoso de. "As categorias do entendimento humano e a noção de tempo e espaço entre os nuer". Série Antropologia, Brasília: Departamento - PPG em Antropologia da UnB, 1993.

OLIVEIRA, Roberto Cardoso de. "A Categoria de 'Entendimento Humano' na Antropologia" In: Sobre o Pensamento Antropológico. RJ: Tempo Brasileiro/Cnpq, 1988.

OLIVEIRA, Roberto Cardoso. "Introdução a uma leitura de Mauss" In: Roberto Cardoso de Oliveira (org.): Mauss. SP: Ática, 1979.

PAIXÃO, Antônio Luiz. "A teoria geral da ação e a arte da controvérsia”. RBCS, no 11, vol. 4, outubro, 1989, p. 34-56.

PARSONS, Talcott. Toward a General Theory of Action. New Brunswick (NY): Transaction Publishers, 195.

PARSONS, Talcott. Social Structure and Personality. New York: The Free Press - London: Collier-Macmillan, 1964.

PARSONS, Talcott. El Sistema Social. Madrid: Revista do Ocidente. 1966

PARSONS, Talcott. La Estructura de la Accion Social. Madrid Guadarrama, 1968, 2 vols.

PARSONS, Talcott. "Durkheim e a teoria da integração dos sistemas sociais" In: Gabriel Cohn (org.): Para Ler os Clássicos. RJ: Livros Técnicos e Científicos, 1977.
PARSONS, Talcott \& SMELSER, N. J. Economy and Society. New York: Free Press, 1956.

PEARS, David. As Idéias de Wittgenstein. SP: Cultrix, 1973, p.162-163.

RICOUER, Paul. A Memória, a História, o Esquecimento. Campinas (SP): Unicamp.

ROCHER, Guy. Talcott Parsons e a Sociologia Americana. RJ: Francisco Alves, 1976.

SMOLKA, Ana Luiz B. "A memória em questão: uma perspectiva histórico-cultural". Educacão \& Sociedade, ano XXI n. 71, julho,

SOUZA, Juliano, STAREPRAVO, Fernando A. e MARCHI JR., Wanderley. "A sociologia configuracional de Norbert Elias potencialidades e contribuições para o estudo do esporte". Rev. Bras. Ciênc. Esporte, Florianópolis, v. 36, n. 2, p. 429-445, abril/junho 2014.

STOCKING JR., George W. Delimiting Anthropology: occasional essays and reflections. Chicago: University of Wisconsin Press, 2001 .

TARDE, Gabriel. Monadologia e Sociologia. Petrópolis (RJ): Vozes, 2003.

TAYLOR, Charles Argumentos Filosóficos. SP: Loyola, 2000 TOMASELLO, Michel. Origens Culturais da Aquisição de Conhecimento Humano. SP: Martins Fontes, 2003.

TREVIÑO, A. Javier. "Introduction: the theory and legacy of Talcott Parsons" In: A. Javier Treviño (org.): Talcott Parsons Today: his theory an legacy in contemporary sociology. N.Y: Rowman \& Littlefield, 2001

TURNER, Jonathan H. \& MARYANSKI, Alexandra. Funcionalism. Menlo Park (California): The Benjamin/Cummings Publishing Company, 1979.

VEYNE, Paul. Como se Escreve a História e Foucault Revoluciona a História. Brasília (DF): UnB, 2008.

WACQUANT, Loïc D. "Introduction" In: Pierre Bourdieu, Réponses. Paris: Seuil, 1992.

WACQUANT, Loïq J. D. "O legado sociológico de Pierre Bourdieu: duas dimensões e uma nota pessoal." Revista Sociologia Política, n. 19, 2002. 
WALLERNSTEIN, Immanuel. O Fim do Mundo como o Concebemos: Ciência Social para o Século XX. RJ: Revan, 2002.

WEINRICH, Harald. Lete: arte e crítica do esquecimento. Rio de Janeiro: Civilização Brasileira, 2001.

WEISZ, George. "The republican ideology and the social sciences; the durkheimians and the history of social economy at the

Sorbonne" In: Philippe Besnard (edit.): The Sociological Domain: the durkheimians and the founding of French sociology. London: Cambridge University - Editions de La Maison des Sciences de

1'Homme, 1983.

WITTGENSTEIN, Ludovic. As Investigações Filosóficas. SP: Abril Cultural, 1979 (Os Pensadores).

YATES, Frances A. The Art of Memory. Chicago: Chicago University Press, 1966. 